\title{
Nomenclature of Cambrian lithostratigraphy of the Skryje-Týřovice Basin
}

\author{
OLDŘICH FATKA, VÁCLAV MICKA, MICHAL SZABAD, VÁCLAV VOKÁČ \& TOMÁŠ VOREL
}

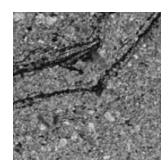

\begin{abstract}
All earlier published concepts and stratigraphical subdivisions of the Cambrian succession in the Skryje-Týřovice Basin are summarized. Forty-two different proposals for lithostratigraphic subdivision published since 1846 are discussed and plotted in seven figures. Here, modified subdivision for the Skryje-Týřovice Basin includes four lithostratigraphic units, the Mileč Member, the Slapnice Member and the Skryje Member, all representing different lithofacies within the newly established Buchava Formation. The whole sedimentary succession contains a rich record of skeletal fauna and is correlated with the Third unnamed Series of the Cambrian System, corresponding to the traditional middle Cambrian Series. - Key word: Buchava Formation, Slapnice Member, Skryje-Týřovice Basin, Teplá-Barrandian region, Cambrian, lithostratigraphy.
\end{abstract}

FATKA, O., MiCKA, V., SZABAD, M., VOKÁČ, V. \& VOREL, T. 2011. Nomenclature of Cambrian lithostratigraphy of the Skryje-Týřovice Basin. Bulletin of Geosciences 86(4), 841-858 (12 figures). Czech Geological Survey. Prague, ISSN 1214-1119. Manuscript received June 1, 2011; accepted in revised form July 27, 2011; published online November 16, 2011; issued November 16, 2011.

Oldřich Fatka, Charles University, Institute of Geology and Palaeontology, Albertov 6, 12843 Prague 2, Czech Republic; fatka@natur.cuni.cz•Václav Micka, Šatrova 662, 14200 Praha 4-Kamýk, Czech Republic; MickaV@seznam.cz - Michal Szabad, Obránců míru 75, 26102 Př́bram VII, Czech Republic; geosvet.pb@seznam.cz・Václav Vokáč, Zábělská 53, 31200 Plzeň, Czech Republic; lichas@seznam.cz•Tomáš Vorel, Czech Geological Survey, P.O. Box 85, Klárov 3/131, 11821 Praha 1, Czech Republic; tomas.vorel@geology.cz

In Central Europe exposures of Cambrian are known in several quite restricted regions like the Franconian Forest, Schwarzburg and Berga anticlines, Vogtland and Lusatia in Germany, Teplá-Barrandian region in Czech Republic and the Holy Cross Mountains in Poland (for general review see Geyer et al. 2008, fig. 4.1.).

More or less complete Cambrian sequences, incorporating all four series, were established only in the Holy Cross Mountains, while incomplete, comparatively restricted sequences are known in the other regions. Quite extensive outcrops of unmetamorphosed development of Cambrian sediments and volcanites occur in the Teplá-Barrandian region, located in central part of the Bohemian Massif. Cambrian rocks are known from three separate areas: in the large Príbram-Jince Basin, in the smaller Skryje-Týřovice Basin and from several diminutive outcrops in the Železné hory area (Fig. 1A).

Cambrian fossils have been collected since the mid $19^{\text {th }}$ century in both the Př́bram-Jince and Skryje-Týřovice basins (see Kraft \& Marek 1992). The first stratigraphical scheme, common to both basins, was proposed in a preliminary report on the "Systême silurien" by Barrande (1846) more than 150 years ago. The scheme was fully explained by Barrande (1852) in the first volume of the "Systême silurien du centre de la Bohême" (Fig. 2A). In Barrande's concept, the oldest fossiliferous levels contained his "faune primordiale" (i.e. Cambrian Series 3 in current terminology); they were part of his Silurian System and were designated as étage $C$. The Cambrian age of étage $C$ was recognized by Marr (1880) for the first time. However, Marr applied "Cambrian" in the Sedgwick's extended sense, embodying also the whole overlying étage $D$ of Barrande (i.e. Ordovician in current terminology). The current lithostratigraphic framework used for the Cambrian of the Skryje-Týřovice Basin has been developed during more than 160 years of continuous research (for earlier reviews see Jahn 1896, Havlíček 1971 and Chlupáč 1999).

The present paper is a comprehensive review and revision of the Cambrian lithostratigraphic units of the Skryje-Týřovice Basin. All the earlier lithostratigraphic schemes are summarized in Figs 2 to 8, completed with a new proposal shown in Fig. 9.

\section{Skryje-Týřovice Basin}

Cambrian sediments crop out only in a narrow zone at the north-western edge of the Krrivoklát-Rokycany Complex 


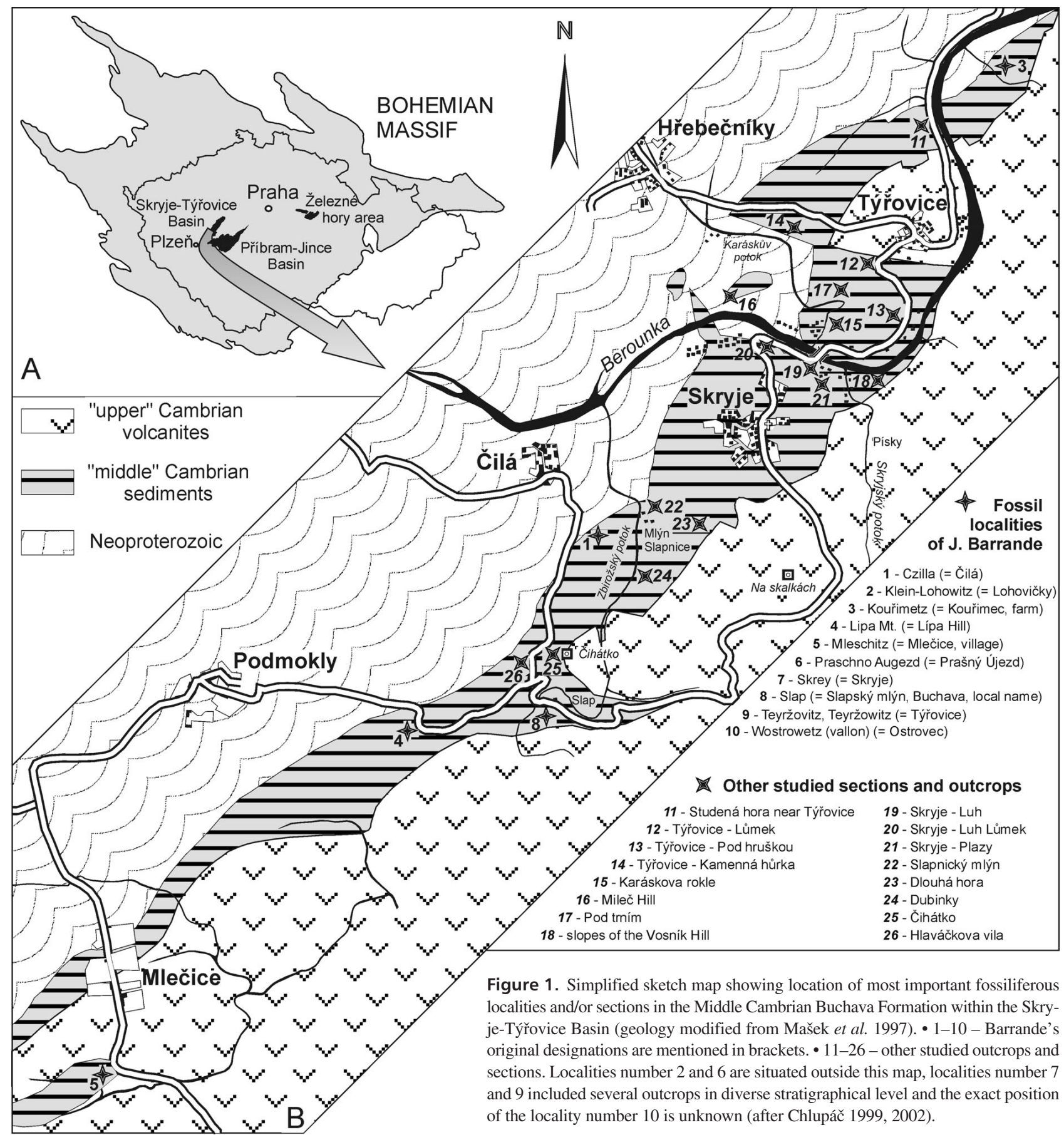

(Fig 1B). A succession of Cambrian sediments (conglomerates, sandstones, graywackes and shales) about $200 \mathrm{~m}$ thick unconformably overlies the slightly metamorphosed Neoproterozoic rocks in the area surrounding the middle course of the Berounka river, north-east of the town Plzeň (Fig. 1B). The Cambrian sedimentary sequence is overlain by extrusive rocks (dacites, andesites and rhyolites) of the Křivoklát-Rokycany Complex, Furongian to earliest Ordovician in age (Drost et al. 2004).

\section{Origination of the basin}

The importance of the Cadomian orogeny for the origination and development of Lower Palaeozoic sedimentary basins in south-western and central Europe (= European peri-Gondwana and/or West Gondwana sensu Vaughan \& Pankhurst 2008) has been adequately perceived and evaluated only in recent years. Linnemann et al. (2008) provided an explanation for the Cadomian orogenic processes and 
the subsequent opening of the Rheic Ocean within the European sector between Spain (Ossa Morena Zone of the Iberian Massif) and central Europe (Saxo-Thuringian and Teplá-Barrandian zones of the Bohemian Massif in Germany and Czech Republic, respectively). They confirmed no sharp break between the Cadomian and the CambroOrdovician tectonic processes and, in agreement with Nance et al. (2002), compared the situation of the above mentioned European sector with a Cordilleran model known from the Cenozoic history of the ridge-continent collision in the Eastern Pacific. Recently, this model was developed in detail for the Neoproterozoic of the Teplá-Barrandian unit by Hajná et al. (2010). Lower Palaeozoic development of the Teplá-Barrandian unit, e.g. the Př́ibram-Jince and Skryje-Týřovice basins (both entirely Cambrian) and Prague Basin (Ordovician to Devonian) was summarized by Patočka \& Štorch (2004) and Fatka \& Mergl (2009).

\section{Description of the succession}

The basal levels are developed as beds of clastic sediments, usually monomict, white to grey conglomerates and sandstones, up to $10 \mathrm{~m}$ thick. They have been interpreted by $\mathrm{Ku}-$ kal (1971) as a high energy succession representing beach coastal barriers and bars. A fragmentarily preserved trilobite, brachiopod and gastropod fauna, initially discovered by Kušta (1884), was studied by Smetana (1918, 1921), Růžička (1939) and Havlíček (1970). The monomict sequence is usually overlain by generally darker, polymict conglomerates and greyish green graywackes to shales with common pebbles of Proterozoic lydites, graywackes and shales. Fragmentary, locally common trilobites and brachiopods were described by Pompeckj (1896), later revised by Šnajdr (1958) and Mergl \& Kordule (2008). Recently, the exceptionally preserved findings of graptoloids and the enigmatic genus Wiwaxia were described by Maletz et al. (2005) and Fatka et al. (2011). The sequence of graywackes and clayey shales with occasional silty to sandy intercalations represents the most widespread lithofacies which may reach up to 200 metres in thickness in some parts of the basin. These fine sediments contain richly diversified associations with common trilobites, agnostids, echinoderms, brachiopods, hyoliths, molluscs, organic-walled microfossils and ichnofossils (for summary see Fatka 1990, 2004; Álvaro et al. 2004; Lefebvre \& Fatka 2003). A new type of mortichnia - ichnofossil associated with its producer preserved in situ was recently described (by Fatka \& Szabad 2011). In the north-eastern part of the Skryje-Týřovice Basin, several tongue-like bodies of the polymict dark conglomerate are developed in the whole thickness of the sequence. Kukal (1971) interpreted the polymict conglomerates, graywackes and shales as depo- sits representing turbidity currents on steep slopes of the sedimentary basin.

\section{Earlier proposed stratigraphical schemes}

Since the middle of the nineteenth century, forty two different, generally correlatable, lithostratigraphic schemes were proposed for the Cambrian sedimentary succession of the Skryje-Týřovice Basin, such that the current lithostratigraphic framework has resulted from more than 160 years of a more or less continuous research. However, all traditional stratigraphical schemes suffer from the lack of designated reference sections in this area. None of the units so far distinguished has been defined by its boundary stratotype.

In this chapter, all the earlier proposed lithostratigraphical schemes are separately discussed in a chronological order; all these schemes are plotted and compared in Figs 2-8.

The first name for fossiliferous Cambrian sediments was published by Barrande (1846) who used the designation "étage C" in combination with locality names (Fig. 2A); Barrande used this designation in all his publications. Hawle \& Corda (1847, p. 132) used two designations, (1) Grauwakke von Skrey (= graywacke from Skrey) and (2) Schiefer von Skrey (= shales from Skrey) for all trilobite specimens originating from the Skryje-Týřovice Basin (Fig. 2B), while Krejčí (1860, p. 467) discerns two different units, (1) "Pískovce Příbramské" (= sandstones from Příbram) and (2) "Vrstvy Jinecké" (= Jince beds) (Fig. 2D). In the same year, Lipold \& Krejčí (1860, p. 89) separated two other units, namely the (1) "Přibramer Grauwacke" (= graywacke of Př́bram) and the (2) "Ginecer Schichten" (= beds of "Gince") (Fig. 2C). In the second edition of the book on geology written in the Czech language, Krejčí (1877, p. 390) used two different names, (1) “Třemošenské slepence" (= Třemošná conglomerates) and (2) "Skrejské břidlice s Faunou primordiální" (= Skreje shales with the Primordial Fauna) (Fig. 2E). Feistmantel (1885, p. 5) preferred to separate units only by indices; (1) " $\mathrm{Cc}_{1}$ slepence $\mathrm{s}$ faunou primordiální" ( $=\mathrm{Cc}_{1}$ conglomerates with the Primordial Fauna) and (2) " $\mathrm{Cc}_{2}$ brridlice $\mathrm{s}$ faunou primordiální" (= $\mathrm{Cc}_{2}$ shales with the Primordial Fauna) (Fig. 2F).

Several complicated and confused schemes were proposed by Kušta (1884-1894), who wrongly applied several names used in the Príbram-Jince Basin also for the Skryje-Týřovice Basin. In his first paper Kušta (1884) mentioned three units, namely: (1) "Třemošnaer Schichten" (= Třemošná beds) or "Třemošnaer Conglomerate" (= Třemošná Conglomerate); (2) "Skrejer Schiefer" (= Skreje Shale) and (3) "grobkörnige dunkle Kieselschiefer-Conglomeraten" (= dark coarse-grained lydite conglomerates) (Fig. 3A). 


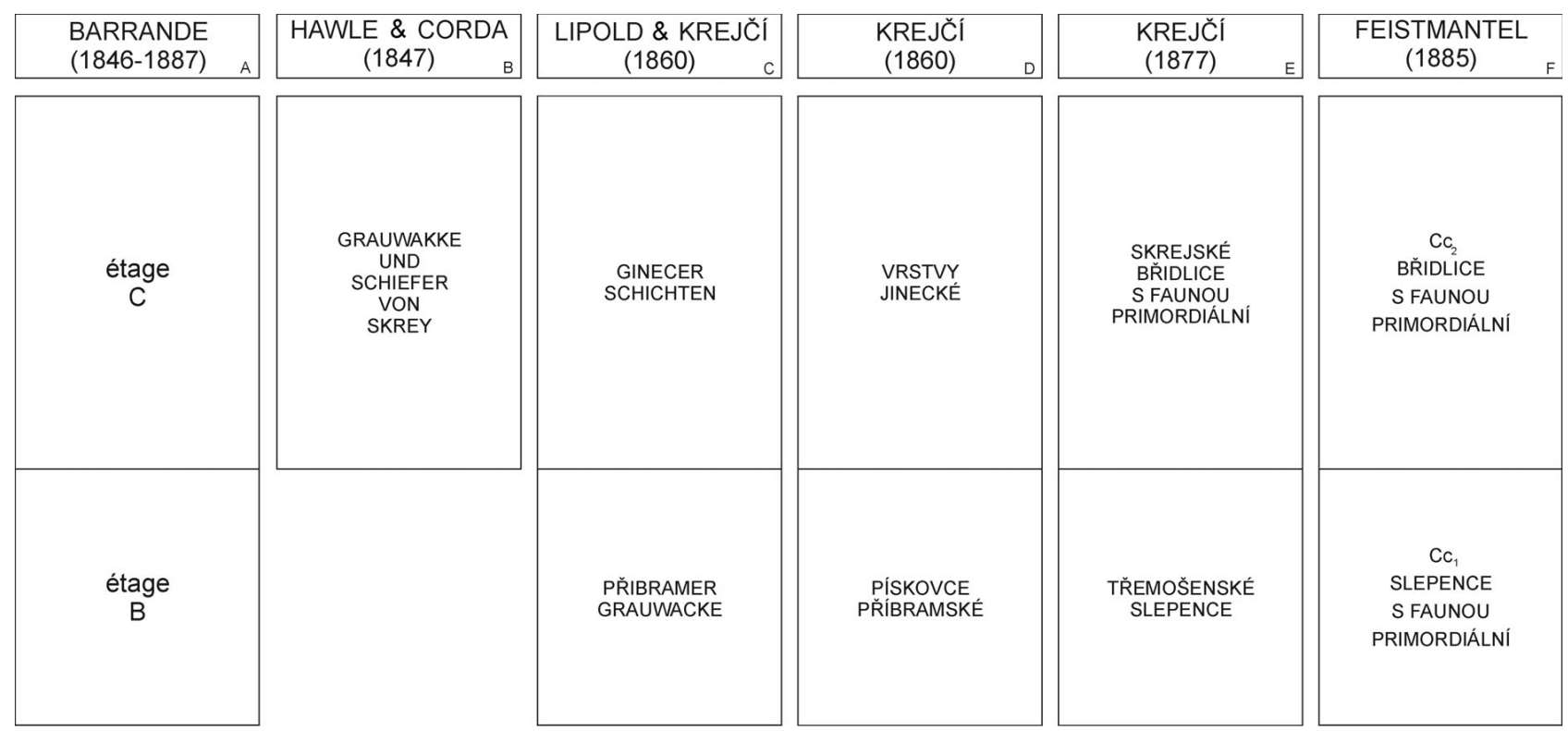

Figure 2. Comparison of lithostratigraphical subdivision of the sediments in the Skryje-Týřovice Basin published between 1846 and 1885.

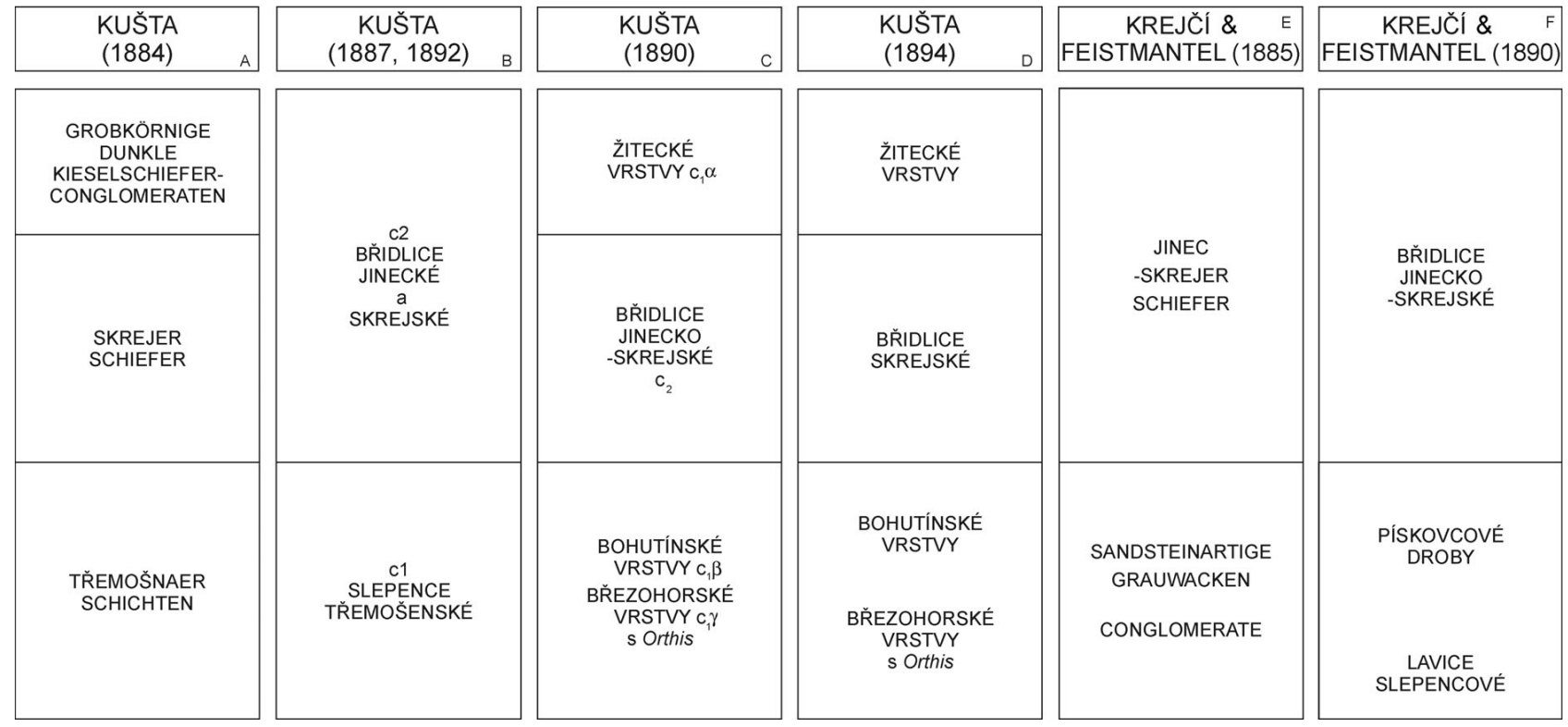

Figure 3. Comparison of lithostratigraphical subdivision of the sediments in the Skryje-Týřovice Basin published between 1884 and 1890.

In the next two papers, only two units were separated (Kušta 1887, p. 690; 1892, p. 143) (1) “c1 - slepence Třemošenské" (= c1 - Třemošná conglomerate) and (2) "c2 - břidlice Jinecké a Skrejské" (= c2 - Jince and Skreje shales) (Fig. 3B), while in his third publication (Kušta 1890), four different names were used: (1) “Žitecké vrstvy $\mathrm{c}_{1} \alpha$ " (= Žitec beds $\mathrm{c}_{1} \alpha$ ) as the uppermost unit; (2) "Břidlice Jinecko-Skrejské c c" (= Jince-Skreje shales $c_{2}$ ); (3) "Bohutínské vrstvy $c_{1} \beta$ " (= Bohutín beds $\left.c_{1} \beta\right)$ for the most fossiliferous levels, and (4) "Březohorské vrstvy (s Orthisy) $c_{1} \gamma$ " [= Březové hory beds (with Orthis) $\left.c_{1} \gamma\right]$. How- ever, Kušta mixed the order of separate units, designating the oldest levels of the Skryje-Týrovice Basin by the name of the youngest units in the Prríbram-Jince Basin and vice versa (cf. Fig. 3C). In his last paper Kušta (1894) attempted to vindicate his earlier correlation with the Příbram-Jince Basin and used names of units without indexes (Fig. 3D). Krejčí \& Feistmantel (1885, p. 22) distinguished also three units designating them as (1) "Conglomerate" (= Conglomerate), (2) "sandsteinartige Grauwacken" (= sandy graywackes) and (3) "Jinec-Skrejer Schiefer" (= Jince-Skreje Shales); five years later, in the Czech edition of 
Oldrich Fatka et al. • Cambrian lithostratigraphy of the Skryje-Týřovice Basin

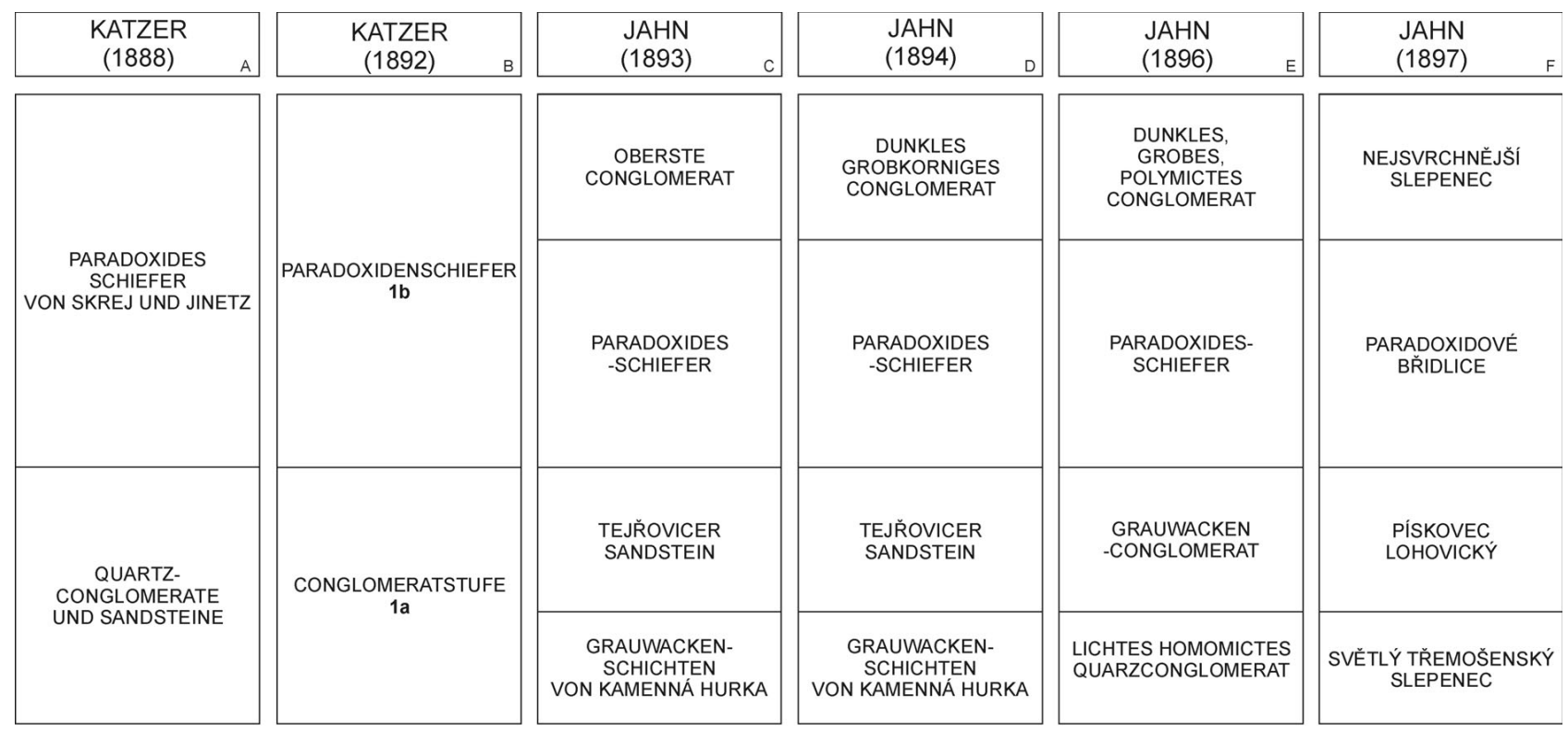

Figure 4. Comparison of lithostratigraphical subdivision of the sediments in the Skryje-Týřovice Basin published between 1888 and 1897.

\begin{tabular}{|c|c|c|c|c|c|}
\hline $\begin{array}{l}\text { POČTA } \\
(1902)\end{array}$ & $\begin{array}{l}\text { POČTA } \\
(1911)\end{array}$ & $\begin{array}{l}\text { KETTNER } \\
(1913)\end{array}$ & $\begin{array}{l}\text { KETTNER } \\
(1916)\end{array}$ & $\begin{array}{l}\text { KETTNER } \\
(1919)\end{array}$ & $\begin{array}{c}\text { KETTNER \& KODYM } \\
(1919)\end{array}$ \\
\hline \multirow{2}{*}{$\begin{array}{c}\text { TMAVÉ } \\
\text { BR̈IDLICEE } \\
\text { JINECKÉ } \\
\text { A SKREJSKÉ } \\
\text { C2 }\end{array}$} & \multirow[b]{2}{*}{$\begin{array}{l}\text { BR̈IDLICE } \\
\text { JINECKÉ } \\
\text { A SKREJSKÉ }\end{array}$} & \multirow[b]{2}{*}{$\begin{array}{l}\text { PARADOXIDOVÉ } \\
\text { BR̃IDLICE }\end{array}$} & $\begin{array}{l}\text { SLEPENCE } \\
\text { DROBOVÉ }\end{array}$ & $\begin{array}{c}\text { TEMNĚ ZELENÉ } \\
\text { POLYMIKTNÍ SLEPENCE } \\
\text { STŘIDÁNÍ } \\
\text { PARADOXIDOVYYCH } \\
\text { BRIIDLIC S TMAVÝMI } \\
\text { SLEPENCI }\end{array}$ & $\begin{array}{l}\text { SLEPENCE } \\
\text { VOSNICKÉ C } \beta^{\prime}{ }^{3}\end{array}$ \\
\hline & & & $\begin{array}{l}\text { PARADOXIDOVÉ } \\
\text { BR̃IDLICE } \\
\text { JINECKO-SKREJSKÉ }\end{array}$ & $\begin{array}{l}\text { PARADOXIDOVÉ } \\
\text { BŔIDLICE }\end{array}$ & $\begin{array}{l}\text { JíLOVITÉ } \\
\text { PARADOXIDOVÉ } \\
\text { BR̃IDLICE } \\
\text { SKREJSKÉ c } \beta^{\prime}{ }_{2}\end{array}$ \\
\hline \multirow{3}{*}{$\begin{array}{l}\text { SLEPENEC A KŘEMIČITY } \\
\text { SVËTLY PISKOVEC } \\
\text { S DROBOVYYM } \\
\text { PISKOVCEM C1 }\end{array}$} & \multirow{3}{*}{$\begin{array}{l}\text { JEMNOZRNNÉ } \\
\text { SLEPENCE, } \\
\text { KREEMENITÉ } \\
\text { A PÍSKOVCE }\end{array}$} & $\begin{array}{l}\text { TEMNÝ SLEPENEC } \\
\text { POLYMIKTNI }\end{array}$ & $\begin{array}{l}\text { PÍSKOVCE } \\
\text { A SLEPENCEE } \\
\text { DROBOVE }\end{array}$ & $\begin{array}{l}\text { DROBOVÉ SLEPENCE } \\
\text { A PÍSKOVCE }\end{array}$ & $\begin{array}{l}\text { DROBOVÉ SLEPENCE } \\
\text { A DROBY TÝŔOVICKÉ C } \beta^{\prime \prime} 1\end{array}$ \\
\hline & & \multirow[t]{2}{*}{$\begin{array}{l}\text { SPODNÍ HOMOMIKTNÍ } \\
\text { SLEPENEC KR̈EMITÝ }\end{array}$} & \multirow{2}{*}{$\begin{array}{l}\text { PISKOOVCE } \\
\text { A SLEPENCCE } \\
\text { KREEMITE }\end{array}$} & $\begin{array}{c}\text { SVEETLE HOMOMMIINTI } \\
\text { SLEPENCE A PISKOVCE } \\
\text { S ORTHIS KUTHANI } \\
\end{array}$ & \multirow{2}{*}{$\begin{array}{l}\text { SLEPENCE A PISKKOVCE } \\
\text { MILEĆSKÉ c } \alpha^{\prime} 4\end{array}$} \\
\hline & & & & BASÁLNÍ BREKCIE & \\
\hline
\end{tabular}

Figure 5. Comparison of lithostratigraphical subdivision of the sediments in the Skryje-Týřovice Basin published between 1902 and 1919.

the same work, Krejčí \& Feistmantel (1890, p. 15) simply translated the names as, (1) "lavice slepencové" (= beds of conglomerates), (2) "pískovcové droby" (= sandy graywackes) and (3) "břidlice Jinecko-Skrejské" (= JinceSkreje shale) (Fig. 3E, F).

Katzer (1888, p. 7) distinguished (1) "Quartzconglomerate und Sandsteine" (= quartzitic conglomerates and sandstones) and (2) "Paradoxides-Schiefer von Skrej und Jinetz" (= Paradoxides shale of Skrej and Jinetz) (Fig. 4A), while in the next paper Katzer (1892, pp. 806, 809) separated the (1) "Conglomeratstufe 1a" (Conglomer- ate stage 1a) and (2) "Paradoxidenschiefer 1b" (Paradoxides shale 1b) (Fig. 4B). Jahn (1893, pp. 268-271) distinguished four different units: (1) "Grauwackenschichten von Kamenná Hůrka" (= Graywacke beds of Kamenná Hůrka), (2) "Tejřovicer Sandstein" (= Tejřovice sandstone), (3) the "Paradoxides-Schiefer" (= Paradoxides shales) and (4) "oberste Conglomerat" (= uppermost conglomerate) (Fig. 4C). In the next year Jahn (1894, p. 148) used slightly changed designation for the youngest level, calling it as "dunkles grobkörniges Conglomerat" (= dark coarse grained conglomerate) (Fig. 4D). In the only com- 
prehensive study of Jahn (1896, pp. 748, 749) the following units were separated: (1) "lichtes homomictes Quarzconglomerat" (= whitish homomict quartzitic conglomerate), (2) "dunkles, grobes, polymictes Grauwacken-Conglomerat mit Sandsteinen und Paradoxidesschiefer" (= dark, coarse-grained, polymict graywacke conglomerate with sandstones and Paradoxides shales), (3) "Paradoxidesschiefer" (= Paradoxides shales), (4) "dunkles, grobes, polymictes Conglomerat" (= dark, coarse-grained, polymict conglomerate) (Fig. 4E). In the Czech language research report, Jahn (1897, pp. 5, 7, 8, $15,16)$ published for the first time not only different names of separate lithostratigraphic units, but completemented their designations by a short lithologic characterisation. In this paper, he used the following four designations: (1) "světlý Třemošenský slepenec" (= whitish Třemošná conglomerate) is characterized as light quartzitic, coarsegrained homomict, (2) "pískovec Lohovický” (= Lohovice sandstone) characterized as fine-grained, soft, quartzitic to graywacke sandstone světlý light to dark polymict, hard), (3) "paradoxidové břidlice" (= Paradoxides shale) and (4) "nejsvrchnější slepenec" (= uppermost conglomerate) characterized as polymict, coarse-grained and dark (Fig. 4F).

A step backward is represented by Počta (1902, pp. 13, 14), who uses two simple descriptive designations (1) "slepenec a křemičitý světlý pískovec s drobovým pískovcem c1" (= conglomerate and quartzitic, whitish sandstone with graywacke sandstone) and (2) "tmavé břidlice jinecké a skrejské c2" (= dark shales of Jince and Skreje) (Fig. 5A). In a geological book written in the Czech language, Počta (1911, pp. 63, 64) changed the names to (1) "jemnozrnné slepence křemenité a pískovce" (= fine-grained quartzitic conglomerates and sandstones) and (2) "břidlice jinecké a skrejské" (= Skreje and Jince shales) (Fig. 5B).

The following years up to the Second World War were dominated by an increased activity by Professor Radim Kettner and his students. The first paper by Kettner was printed in Czech (1913) with a German version (1914). Kettner (1913, p. 5; 1914, p. 8) suffices with four units, (1) "spodní homomiktní slepenec křemitý" (equal to: lichtes homomiktes Quarzkonglomerat; = lower homomict quartzitic conglomerate), (2) "vrstvy pískovcové" (equal to: Sandsteinschichten; = sandstone layers), (3) "temný slepenec polymiktní" (equal to: dunkles, grobes, polymiktes Grauwackenkonglomerat; = dark polymict conglomerate) and (4) "paradoxidové břidlice" (equal to: Paradoxides-Schiefer; = Paradoxides shales) (Fig. 5C).

In his next paper, Kettner (1916, p. 88) changed the names into (1) "pískovce a slepence křemité" (= quartzitic sandstones and conglomerates), (2) "paradoxidové břidlice jinecko-skrejské a pískovce a slepence drobové" (= Paradoxides shales of Jince and Skreje and sandstones and graywacke conglomerates), (3) "slepence drobové"
(= graywacke conglomerates) (Fig. 5D). However, production of different schemes continued, and the next alteration appeared only three years later, when Kettner (1919, pp. 11-13, stratigraphic table) used the seven designations, as follows: (1) "basální brekcie" (= basal beccia), (2) "světlé homomiktní slepence a pískovce a křemité pískovce s Orthis kuthani" (= whitish homomict conglomerates and sandstones and quartzitic sandstones with Orthis kuthani), (3) "tmavé polymiktní slepence a 'Orthisové' pískovce drobové" (= dark polymict conglomerates and "Orthis" graywacke sandstones), (4) "drobové pískovce a slepence, resp. drobové pískovce" (= graywacke sandstones and conglomerates, graywacke sandstones), (5) "paradoxidové břidlice" (= Paradoxides shales), (6) "stř̌idání paradoxidových břidlic s tmavými slepenci" (= interfingering of the Paradoxides shales and dark conglomerates), and (7) "temně zelené polymiktní slepence" (dark green polymict conglomerates) (Fig. 5E). In the same year, Kettner \& Kodym (1919, p. 6) and later on also Kettner (1940, pp. 14-17) distinguished four units, (1) "slepence a pískovce milečské c $\alpha{ }_{4}$ " (= Mileč conglomerate and graywackes $\left.c \alpha^{\prime}{ }_{4}\right),(2)$ "polymiktní drobové slepence a droby tejřovické $\mathrm{c} \beta$ ' ${ }_{1}$ " (= polymict Tejřrovice conglomerates and graywackes $c \beta$ ' ${ }_{1}$ ), (3) "jílovité paradoxidové břidlice skrejské c $\beta$ ' ${ }_{2}$ " (= Skryje Paradoxides shales c $\beta{ }_{2}$ ), (4) "slepence vosnické c $\beta$ ' " (= Vosník conglomerates $\mathrm{c} \beta{ }_{3}$ ) (Fig. 5F). However, six units were used by Kettner (1922, p. 128), (1) "basální brekcie” ze spilitického materiálu (= basal beccia composed from spilitic material), (2) "slepence a pískovce milečské (křemité) $\mathrm{c}^{\prime}{ }_{4}$ " (= quartzitic Mileč conglomerates and sandstones $\mathrm{c} \alpha^{\prime}{ }_{4}$ ), (3) "Orthisové pískovce $\mathrm{c} \beta{ }_{1}$ " (= "Orthis" sandstones $\mathrm{c} \beta$ ' ${ }_{1}$ ), (4) drobové "slepence a droby tejř̌ovické" (polymiktní sedimenty) $\mathrm{c} \beta{ }^{\prime}{ }_{1}$ (= Tejřovice polymict graywacke conglomerates and graywackes $\mathrm{c} \beta{ }_{1}$ ), (5) "břidlice skrejské (paradoxidové jílovité břidlice) $\mathrm{c} \beta_{2}$ " (= Skreje Paradoxides clayey shales $c \beta_{2}$ ), (6) "slepence vosnické $\mathrm{c} \beta_{3}^{\prime}$ " (polymiktní s bohatým klastickým materiálem spilitickým c $\left.\beta_{3}^{\prime}\right)(=$ Vosník conglomerate, polymict with common spilitic clasts $\mathrm{c} \beta{ }_{3}$ ) (Fig. 6A). In the next year, Kettner (1923) continued in reducing names and applies four names only, (1) "slepence a pískovce milečské" (světlé homomiktní křemité) (= Mileč conglomerates and sandstones, whitish, homomict, quartzitic), (2) "slepence a pískovce tejřrovické" (orthisové pískovce a temné polymiktní drobové slepence) (= Tejřovice conglomerates and sandstones, Orthis sandstones and dark polymict, graywacke conglomerates), (3) "brridlice skrejské" (paradoxidové břidlice) (= Paradoxides Skryje shales), and (4) "slepence vosnické" (= Vosník conglomerates) (Fig. 6B). In the explanatory report the map for the SW sector of the Skryje-Týřovice area, Andrusov (1925, pp. 57-59) differentiated the (1) "homomiktní slepence a křemité pískovce (ekvivalenty slepenců milečských)" (= homomict con- 


\begin{tabular}{|c|c|c|c|c|c|}
\hline $\begin{array}{l}\text { KETTNER } \\
(1922)\end{array}$ & $\begin{array}{l}\text { KETTNER } \\
(1923)\end{array}$ & $\begin{array}{l}\text { ANDRUSOV } \\
(1925) \\
\end{array}$ & \begin{tabular}{|cr} 
KETTNER \& SLAVÍK \\
$(1928)$
\end{tabular} & $\begin{array}{cr}\text { KETTNER \& BOUČEK } \\
(1936) & \mathrm{E} \\
\end{array}$ & $\begin{array}{l}\text { BOUČEK (1941), } \\
\text { PRANTL (1942) F }\end{array}$ \\
\hline $\begin{array}{l}\text { SLEPENCE } \\
\text { VOSNICKÉ Cß'3}{ }^{\prime}\end{array}$ & $\begin{array}{l}\text { SLEPENCE } \\
\text { VOSNICKÉ }\end{array}$ & \multirow{2}{*}{$\begin{array}{c}\text { DROBOVÉ PÍSKOVCE } \\
\text { A BŘIDLICE }\end{array}$} & $\begin{array}{l}\text { SLEPENCE } \\
\text { VOSNICKÉ }\end{array}$ & $\begin{array}{l}\text { CONGLOMÉRATS } \\
\text { DU VOSNÍK C } \beta^{\prime}{ }_{3}\end{array}$ & $\begin{array}{l}\text { SLEPENCE } \\
\text { VOSNICKÉ } \mathrm{C} \beta^{\prime}{ }^{\prime}\end{array}$ \\
\hline $\begin{array}{c}\text { BŘIIDLICE } \\
\text { SKREJSKÉ c } c \beta^{\prime} 2\end{array}$ & $\begin{array}{l}\text { BŘIDLICE } \\
\text { SKREJSKÉ }\end{array}$ & & $\begin{array}{c}\text { SKREJSKÉ } \\
\text { BŘIDLICE } \\
\text { PARADOXIDOVÉ }\end{array}$ & $\begin{array}{c}\text { SCHISTES } \\
\text { A PARADOXIDES } \\
\text { DE SKRYJE c } \beta^{\prime 2}\end{array}$ & $\begin{array}{c}\text { BŘIDLICE } \\
\text { SKRYJSKÉ c } \beta^{\prime 2}\end{array}$ \\
\hline $\begin{array}{l}\text { DROBOVÉ SLEPENCE } \\
\text { A DROBY TÝROVICKÉ c } \beta^{\prime} \text {, } \\
\text { A ORTHISOVÉ PÍSKOVCE }\end{array}$ & $\begin{array}{c}\text { SLEPENCE A PÍSKOVCE } \\
\text { TEJRKOVICKÉ }\end{array}$ & DROBOVÉ PÍSKOVCE & $\begin{array}{l}\text { SLEPENCE } \\
\text { TÝROVICKÉ }\end{array}$ & $\begin{array}{c}\text { CONGLOMÉRATS ET GRÈS } \\
\text { DU TÝŔROVICE c } \beta^{\prime \prime} 1\end{array}$ & $\begin{array}{l}\text { PÍSKOVCE ČI SLEPENCE } \\
\text { A DROBY TÝŘOVICKÉ c } \beta^{\prime 1}\end{array}$ \\
\hline $\begin{array}{l}\text { SLEPENCE A PÍSKOVCE } \\
\text { MILEČSKÉ c } \alpha^{\prime} 4\end{array}$ & \multirow{2}{*}{$\begin{array}{l}\text { SLEPENCE } \\
\text { A PIISKOVCE } \\
\text { MILEČSKÉ }\end{array}$} & \multirow[t]{2}{*}{$\begin{array}{l}\text { HOMOMIKTNÍ SLEPENCE } \\
\text { A KŘEMITÉ PISKOVCE }\end{array}$} & \multirow[t]{2}{*}{$\begin{array}{l}\text { SLEPENCE } \\
\text { MILEČSKÉ }\end{array}$} & \multirow[t]{2}{*}{$\begin{array}{c}\text { CONGLOMÉRATS ET GRÈS } \\
\text { DU MILEĆ }\left(c \alpha^{\prime} 4\right)\end{array}$} & \multirow[t]{2}{*}{$\begin{array}{c}\text { PÍSKOVCE ČI SLEPENCE } \\
\text { MILEČSKÉ CO } 4^{\circ}\end{array}$} \\
\hline BASÁLNÍ BREKCIE & & & & & \\
\hline
\end{tabular}

Figure 6. Comparison of lithostratigraphical subdivision of the sediments in the Skryje-Týřovice Basin published between 1922 and 1942.

glomerates and quartzitic sandstones; equal to Mileč conglomerates), (2) "drobové pískovce" (= graywacke sandstones), and (3) "střídání drobových pískovců a břidlic" (= interfingering of sandstones and shales) (Fig. 6C).

The more or less final version of their research was published by Kettner \& Slavík (1928, pp. 7, 8), who distinguished (1) "slepence milečské" (= Mileč conglomerates), (2) "slepence týřovické" (= Týřovice conglomerates), (3) "skrejské břidlice paradoxidové" (= Paradoxides Skreje shales), and (4) "slepence vosnické" (= Vosník conglomerates) (Fig. 6D).

Kettner \& Bouček (1936, tab. III. Cambrien) published a French version of the simple division into four units with (1) "Conglomérats et grès du Mileč $\left(\mathrm{c} \alpha_{4}{ }_{4}\right)$ " (= Mileč conglomerates and graywackes - $\mathrm{c}^{\prime}{ }_{4}$ ); (2) "Conglomérats et grès du Týřovice $\left(\mathrm{c} \beta{ }_{1}{ }_{1}\right)$ " (= Týřovice conglomerates and graywackes - c $\beta$ ' $\left.{ }_{1}\right)$; (3) "Schistes à Paradoxides de Skryje $\left(\mathrm{c} \beta^{\prime}{ }_{2}\right) "$ (= Skryje shales with Paradoxides $\left.-\mathrm{c} \beta{ }_{2}\right)$, and (4) "Conglomérats du Vosník ( $\left.\beta_{3}{ }_{3}\right)$ " (= Vosník conglomerates $-\mathrm{c} \beta_{3}$ ) (Fig. 6E). Bouček (1941, p. 12) as well as Prantl (1942, pp. 271, 272) shortly characterized four units, namely, (1) "pískovce či slepence milečské (c $\left.\alpha_{4}{ }_{4}\right)$ " (= Mileč sandsones or conglomerates $-c \alpha_{4}{ }_{4}$ ), (2) "pískovce či slepence a droby týřovické $\left(c \beta{ }^{\prime}{ }_{1}\right)$ " (= Tejřovice sandstones or conglomerates and graywackes - c $\beta^{\prime}{ }_{1}$ ), (3) "břidlice skryjské $\left(\mathrm{c} \beta_{2}{ }_{2}\right)$ " (= Skryje shales $\left.-\mathrm{c} \beta^{\prime}{ }_{2}\right)$, (4) "slepence vosnické (c $\left.\beta_{3}{ }_{3}\right)$ " (= Vosník conglomerates $\mathrm{c} \beta^{\prime}{ }_{3}$ ) (Fig. 6F). Růžička (1944, p. 10) mentioned only three older units, calling them (1) "c $\alpha_{4}$ - křemité pískovce" (= $c \alpha_{4}$ - quartzitic sandstones), (2) “c $\beta{ }_{1}-$ orthisové pískovce" (= c $\beta{ }_{1}$ - Orthis sandstones) and (3) "c $\beta{ }_{2}-$ paradoxidové břidlice" (= $\mathrm{c} \beta{ }_{2}-$ Paradoxides shales) (Fig. 7A).
After the Second World War, lithologic characterisation of the four units, called facies, was summarized by Kodym (1948, pp. 54-56), namely: (1) “vrstvy milečské $\mathrm{c}^{\prime}{ }_{4}{ }^{\prime}$ " (= Mileč layers $\mathrm{c} \alpha^{\prime}{ }_{4}$ ); (2) "pískovce a slepence týřovické c $\beta$ ' " " (= Týřovice conglomerates and sandstones $\left.\mathrm{c} \beta^{\prime}{ }_{1}\right)$; (3) "paradoxidové břidlice skryjské c $\beta$ ' ${ }_{2}$ " (= Skryje Paradoxides shales c $\beta$ ' ${ }_{2}$ ) and (4) "slepence vosnické c $\beta$ ', (= Vosník conglomerates $\mathrm{c} \beta_{3}{ }_{3}$ ) (Fig. 7B). Only slightly changed was the scheme published five years later (Kodym 1953; pp. 66-68), (1) "milečské slepence a orthisové pískovce c $\beta$ ' " (= Mileč conglomerates and Orthis sandstones $c \beta$ ' $\left.{ }_{1}\right),(2)$ "pískovce a slepence týřovické $c \beta$ ' ${ }_{2 a}$ ", (= Týŕovice conglomerates and sandstones c $\beta$ ' ${ }_{2 \mathrm{a}}$ ), (3) "paradoxidové břidlice skryjské $\mathrm{c} \beta$ ' ${ }_{2 \mathrm{~b}}$ " (= Skryje Paradoxides shales $\mathrm{c} \beta{ }^{2 \mathrm{~b}}$ ), and (4) "slepence vosnické c $\beta$ ' $2 \mathrm{~b}$ " (= Vosník conglomerates $\mathrm{c} \beta$ ' ${ }_{2 \mathrm{~b}}$ ) (Fig. 7E). A simple division was used by Bouček (1951, pp. 12, 13), who discriminated (1) "křemité slepence milečské (c $\beta$ ' $\left.{ }_{1 \mathrm{a}}\right)$ " (= quartzitic Mileč conglomerates - $\mathrm{c} \beta{ }^{\prime}{ }_{1 \mathrm{a}}$ ), (2) "pískovce týřovické = orthisové $\left(\mathrm{c} \beta{ }^{\prime}{ }_{1 \mathrm{~b}}\right)$ " (= Týŕovice sandstones = Orthis $\left.-\mathrm{c} \beta^{\prime}{ }_{1 \mathrm{~b}}\right)$; (3) "břidlice skryjské $\left(\mathrm{c} \beta{ }_{2}{ }_{2}\right)$ " (= Skryje shales - c $\beta{ }_{2}$ ); and (4) "slepence vosnické (c $\beta$ ' $\left.{ }_{3}\right)$ " (= Vosník conglomerates $\mathrm{c} \beta_{3}$ ) (Fig. 7C). Also Petránek (1952a, pp. 8, 9; 1952b, p. 221) provided an altered scheme, designating Orthis sandstone as a separate unit and proposing the "Skryje formation", which he subdivided into the Skryje shale and the Vosník conglomerate, thus using the seven following units: (1) "Milečské vrstvy" včetně bazální brekcie (= Mileč Formation including the basal beccia), (2) "Orthisový pískovec" (= Orthis sandstone), (3) "Týřovický slepenec" (= Týřovice conglomerate), (4) "Skryjské vrstvy" (= Skryje Formation), (5) "Skryjské břidlice" (= Skryje shale) and (6) "Vosnický slepenec" (= Vosník 


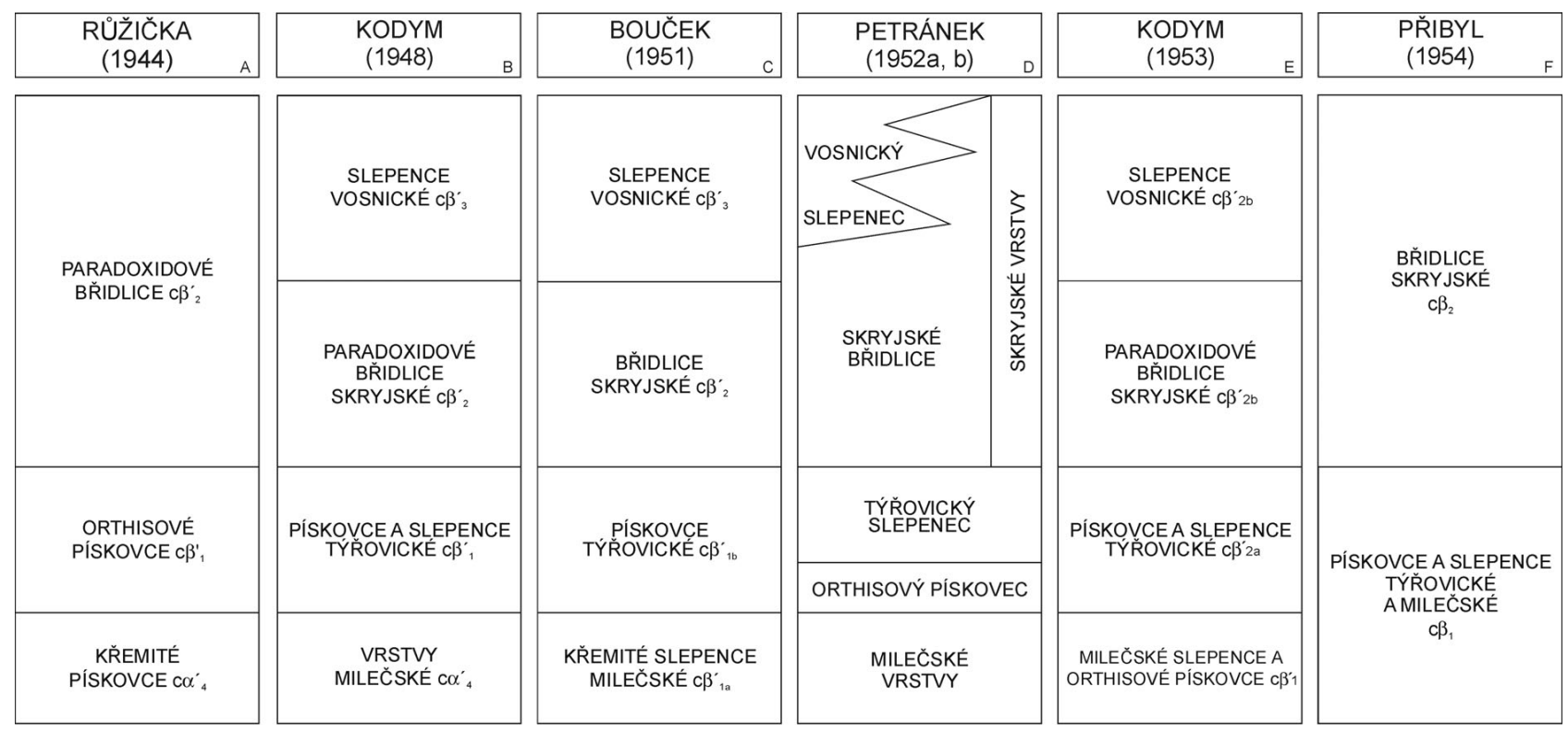

Figure 7. Comparison of lithostratigraphical subdivision of the sediments in the Skryje-Týřovice Basin published between 1944 and 1954.

conglomerate) (Fig. 7D). Přibyl (1954, p. 14) separated (1) "pískovce a slepence týřovické a milečské c $\beta_{1}$ " (= Mileč and Týřovice sandstones and conglomerates $\mathrm{c} \beta_{1}$ ), and (2) "břidlice skryjské c $\beta_{2}$ " (= Skryje shales $\mathrm{c} \beta_{2}$ ) (Fig. 7F). Substantial changes in the general understanding of the Barrandian area, including stratigraphy of the Skryje-Týrovice area, are associated with the mapping performed by the Státní geologický ústav Československé republiky (now Czech Geological Survey Prague) after the Second World War. The research of Cambrian successions was realised by Havlíček \& Šnajdr between 1950 and 1970 and resulted in formal changes in stratigraphic nomenclature.

In the first phase of their research, Havlíček \& Šnajdr (1951, pp. 163, 164) and Šnajdr (1956, p. 54; 1958, pp. 19-21) connected the Mileč and Týřovice conglomerates and sandstones together and distinguished thus only two lithostratigraphic units, namely the (1) "vrstvy milečsko-týřovické $\left(\mathrm{c} \beta_{1}\right)$ " (= Mileč-Týřovice beds $\left.-\mathrm{c} \beta_{1}\right)$ and (2) "vrstvy skryjské $\left(c \beta_{2}\right)$ " (= Skryje beds $\left.-c \beta_{2}\right)($ Fig. 8A). This subdivision was applied also by Havlíček et al. (1958).

Later on, Havlíček (1966, pp. 103-105; 1971, pp. 31-35; 1992, p. 47; 1998, pp. 32, 33) embodied all sediments in the Jince Formation and followed the earlier schemes in separating the traditional four units - (1) "milečské pískovce a slepence", včetně tzv. orthisových pískovců, (= Mileč Conglomerates and Sandstones including the "Orthis" Sandstones), (2) "týřovické droby a slepence" (= Týřovice Graywackes and Conglomerates), (3) "skryjské břidlice" (= Skryje Shales) and (4) "vosnické slepence" (= Vosník Conglomerates), all of them treated as members of the Jince Formation (Fig. 8B). Kukal (1971) included the
Vosník Conglomerates in the Týřovice Conglomerates and reduced thus the number of members into four, namely: (1) "Mileč Conglomerates", (2) "Orthis Sandstones", (3) "Týřovice Conglomerates" and (4) "Skryje Shales" (Fig. 8C).

Another slightly modified lithostratigraphic scheme was published by Havlíček (1994), who, without any explanation, divided Cambrian sediments into the older Mileč Formation (1), which was capped by the Jince Formation (2), composed of the Týřovice Conglomerate (3), Skryje Shales (4) and Vosník Conglomerate (5), all of them treated as members (Fig. 8D).

Similarly Kordule (2006, fig. 12) designated the oldest conglomerates and sandstones as the Mileč Formation, while the overlying sediments of the Jince Formation were divided in two members only, in the Skryje Shale and in the Týřovice Conglomerate and Graywacke (Fig. 8E). However, in the following figure 13 of Kordule (2006), the third unit, the Vosník Conglomerate re-appeared. Recently, Mergl \& Kordule (2008, p. 12) applied only three names, (1) "Mileč Conglomerates", (2) "Týřovice Graywackes and Conglomerates" and (3) "Skryje Shales"; they did not use these units within the Jince Formation (Fig. 8F). Fatka in Geyer et al. (2008, fig. 4.20) and Fatka \& Mergl (2009, fig. 7) used the traditional subdivision of the Jince Formation and distinguished four members.

All the earlier schemes and the revised lithostratigraphic concept adopted in this paper are shown in Figs 2-8.

The name "Ginecer Schichten" was first used by Lipold \& Krejčí (1860) (Fig. 2C) for the former "étage C" of Joachim Barrande. Krejčí (1877) for the first time proposed 

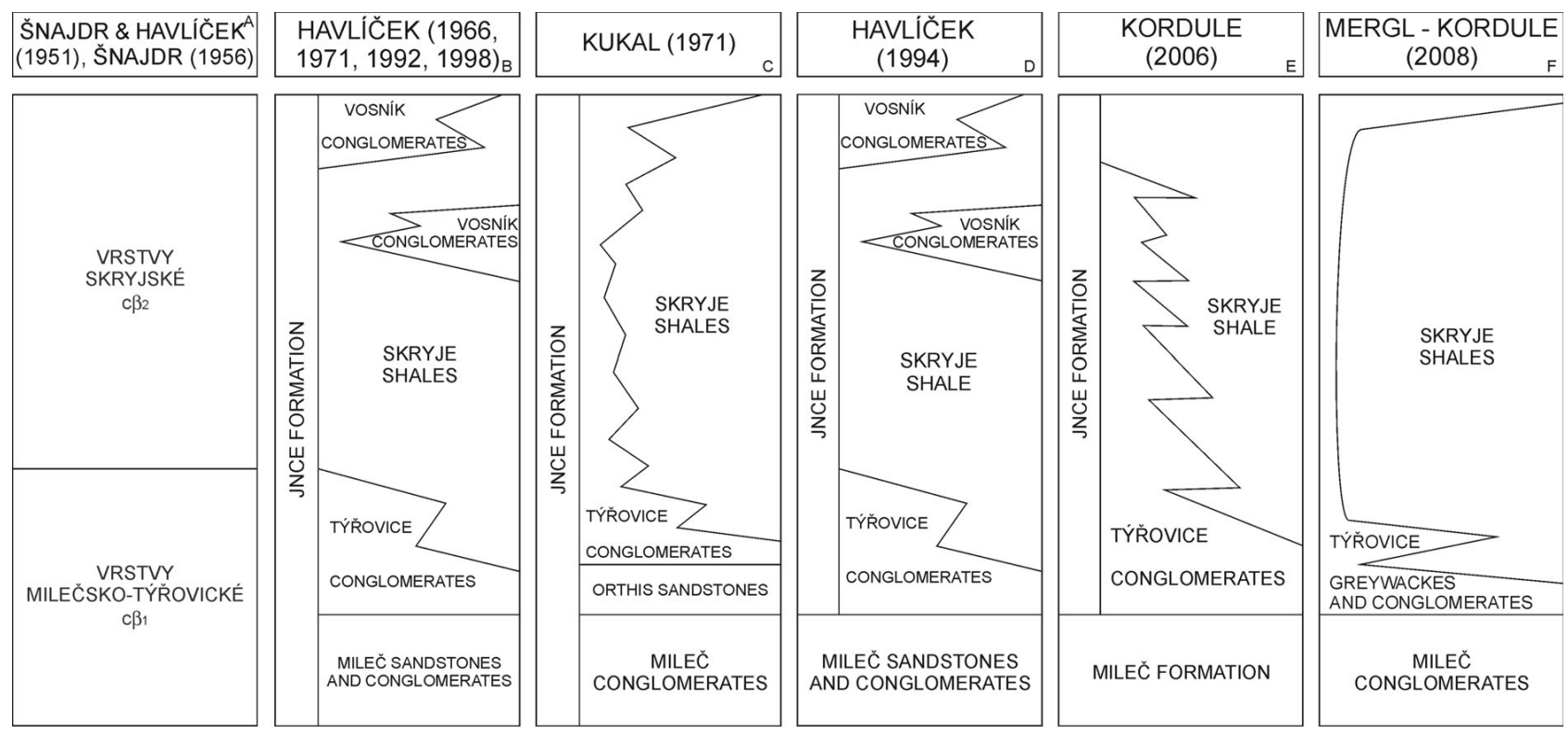

Figure 8. Comparison of lithostratigraphical subdivision of the sediments in the Skryje-Týřovice Basin published between 1951 and 2008.

the designation "skrejské břidlice s faunou primordiální" for fossiliferous sediments in the Skryje-Týřovice Basin (Fig. 2E). Middle Cambrian fossils from both basins were reported already in the early $19^{\text {th }}$ century, but the palaeontological research culminated in the studies of Joachim Barrande, who published seven volumes (in reality printed as 22 books) of his "Systême silurien du centre de la Bohême" in the period 1852-1887. Since then, the Barrandian area has occupied a special position among the classical Lower Palaeozoic regions.

Barrande's extensive palaeontological material from the "étage C" originated from several tens of fossil sites. Because he and his collaborators used generalized designations for localities, only the following eight names are used on labels as Cambrian localities within the Skryje-Týřovice Basin (Chlupáč 1999; Czilla (moulin) = now Čilá, Klein-Lohowitz = now Lohovičky, Kouřimetz = now Kouřrimec (farm), Lipa Mt. = now Lípa, Mleschitz = now Mlečice (village), Praschno Augezd = now Prašný Újezd (village), Skrey = now Skryje (village), Slap = now Slapský mlýn, Buchava or Podmokelský mlýn (local name), Teyržovitz, Teyržowitz = now Týřovice (village), Wostrowtz $($ vallon $)=$ now Ostrovec $($ Fig. 1B $)$.

\section{New proposal}

The designation "Jince Formation" proposed by Lipold \& Krejčí (1860) was subsequently used for fossiliferous Middle Cambrian sediments of the Prríbram-Jince Basin by all later authors. However, it has been applied also for coeval Cambrian sediments of the Skryje-Týrrovice Basin. Be- cause the areas of Middle Cambrian marine sediments were deposited in at least two separate and only indirectly connected areas, in the Prríbram-Jince and in the SkryjeTýřovice basins, different litholostratigraphical units should be used for each of the basins.

In the Skryje-Týřrovice Basin, one major transgressive-regressive cycle is developed (Fatka \& Mergl 2009). It starts with mature basal clastics (represented by the quartzitic, usually monomict conglomerates and sandstones of the Mileč Member containing well rounded pebbles and residual quartz-grains from the earlier weathered regolith (Fig. 12A). However, at some outcrops, thin lenses of monomict conglomerates composed of well rounded quartz pebbles and grains do also occur in stratigraphically high levels of the Skryje Member, e.g. at the Včelín locality (200 metres SSE of the locality Plazy, Fig. 1B/21).

Mileč Member is followed by generally finer and less mature sediments of coarse grained sandstones, graywackes and occasionally shales of the Slapnice Member (former usual designation - Týřovice graywackes). This member is characterized by a less mature matrix in which poorly sorted but generally well rounded grains and rarely pebbles of silicites and quartz are irregularly dispersed (Fig. 12C, D). Such a lithology predominates in lower stratigraphical levels of the sequence, and generally prevails in the NE sector of the preserved part of the basin. The most characteristic is the occurrence of conglomerates with graywacke matrix, earlier designated as the Vosník Conglomerate.

Retention of a lithostratigraphical term is suggested in two cases only, the Mileč Member and the Skryje Member. As non-geographic names do not meet the recommenda- 

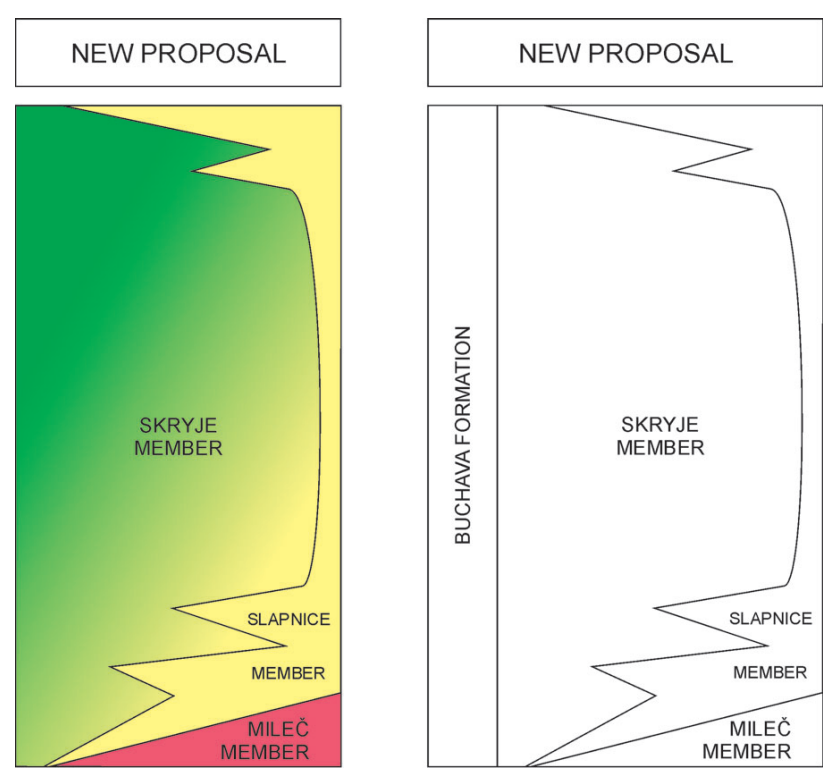

Figure 9. New proposal of lithostratigraphical subdivision of the sediments in the Skryje-Týřovice Basin.

tions of the International Stratigraphic Guide (Salvador 1994), the "Orthis Sandstone" is suppressed.

\section{Definitions of lithostratigraphical units}

\section{Mileč Member (Kettner \& Kodym 1919, p. 6, emended and formalized)}

Derivation of name. - The name refers to the stratotype locality.

Stratotype. - Natural outcrops on the top of Mileč Hill are designated as the stratotype section (Fig. 1B/16, Fig. 10A). This basal stratotype of the Mileč Member represents contemporaneously also the basal stratotype of the Buchava Formation.

Boundaries. - Basal conglomerates and/or breccias of the Mileč Member unconformably overlie the Neoproterozoic and in turn they are overlain by the Slapnice Member.
Lithology. - Monomict clastic material is composed by quartz, silicites, silicified shales occasionally quartzites. Quartz dominates, the other components commonly represent only admixture. Quartzitic grains, usually represented by monocrystals (mainly in sandy admixture), or coarse polycrystals, or both, are always well rounded. Pebbles of silicites are microcrystalline, some of them are dark because of the contained organic matter. Grain contacts are locally cracked and/or fused due to pressure. The matrix is silicified, mainly finely recrystalized into microcrystalline quartz, weathered parts contain hematite admixture (Fig. 12A).

In higher levels of the sequence, conglomerates pass into sandstones (earlier designated as the "Orthis" sandstones, e.g. by Kettner 1922) characterized by higher content of clay matrix. In these levels, dominating quartz grains are subangular to sharply edged (Fig. 12B). This transitional change fits well with the general passage into the sedimentation of graywackes indicated by the overlying levels.

Environment. - The occurrence of marine skeletal fauna (Růžička 1939) combined with the very good sorting and perfect roundness of quartz grains and pebbles are interpreted as indicating the deposition in beaches, coastal barriers and bars by Kukal (1971).

The generally high level of sorting, rounding of pebbles combined with the very high content of stable components have been interpreted as markers of shallow-water environment, corresponding to beach sands and gravels. The nature of quartzitic grains and the other lithoclasts fit well with their provenance from the adjacent Neoproterozoic sequences (see also Drost et al. 2004, 2007).

Discussion. - All earlier data were summarized by Kukal (1970) in an unpublished report. Later, Kukal (1971, pp. 79, 80) characterized the "Mileč Conglomerates" as well sorted sediments with all transitional stages from coarse to medium grained sandstones to conglomerates typified by the prevalence of the fraction of $2 \mathrm{~mm}$ to $1 \mathrm{~cm}$. Pebbles are generally well rounded. Conglomerates contain more than 90 per cent of quartz and silicites.

Remarks. - This name, initially proposed by Kettner \& Kodym (1919, p. 6) has been used by all following authors.

Figure 10. Skryje-Týřovice Basin, outcrops and lithotypes of the Buchava Formation. • A - natural outcrops in conglomerates on the top of the Mileč Hill, stratotype section of the Mileč Member; Fig. 1B/16. • B - well sorted monomict medium grained sandstones to fine conglomerates with the prevailing fraction of $2 \mathrm{~mm}$ to $1 \mathrm{~cm}$ showing prevalence of well rounded pebbles of quartz and silicites; Mileč Member at the Mileč Hill. $\bullet \mathrm{C}-$ natural outcrops of the Mileč Member with large boulders of cherts cropping out in the SW slope near the Slapnický mlýn, about 150 metres south of the locality 22. • D - Skryje-Luh lůmek (= small quarry, Fig. 1B/20), lower part of the Buchava Formation with the Mileč Member (MM) overlain by the former "Orthis Sandstones" (Orthis) and lower levels of the Slapnice Member (SIM). • E, F - section at the Studená hora near Týřovice, conglomerates in higher levels of the Slapnice Member showing large pebbles of cherts (Fig. 1B/11). Lithofacies earlier designated as "Vosník conglomerates and sandstones". 

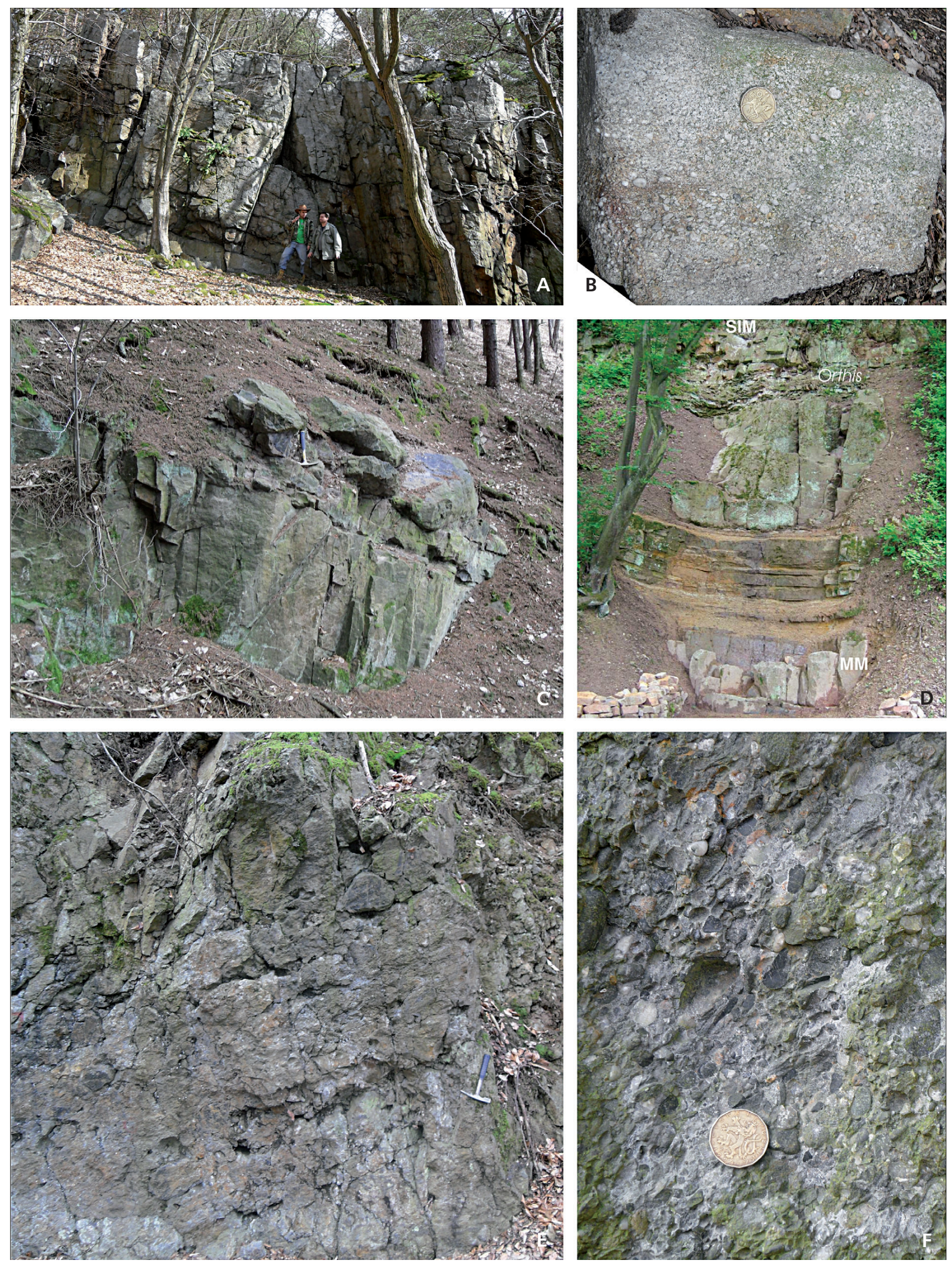


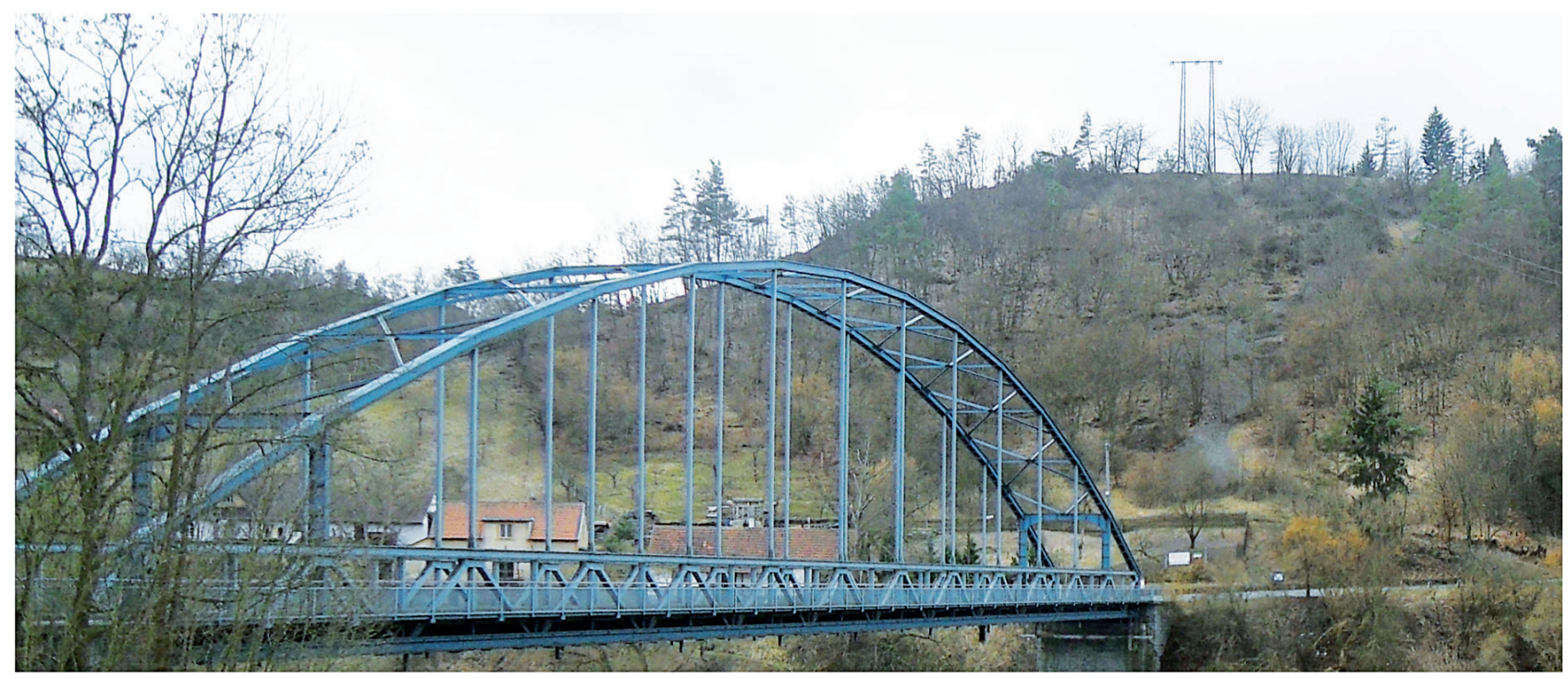

Figure 11. Skryje-Týřovice Basin, classical natural outcrops in shales in northern slope designated Skryje-Luh locality; stratotype section of the Skryje Member (Fig. 1B/19).

A majority of them preferred to separate it as an independent stratigraphical unit, usually a member, but see Havlíček (1994) and Kordule (2006). Occurrence of lenses of the typical "Mileč" lithotype (e.g. monomict quarzitic conglomerates and sandstones) within shales and graywackes (for instance at the Skryje-Plazy locality, outcrop called "Pod včelínem") demonstrates the need to classify this lithofacies as a member within a higher lithostratigraphical unit.

\section{Slapnice Member (new)}

Derivation of name. The member is named after the stratotype locality at Slapnice.

Stratotype. - Natural outcrops on the left bank of the Zbirožský potok valley east of the former Slapnický mlýn is designated here as the stratotype section. These outcrops display older levels than Barrande's locality Čilá (Fig. 1B/1).
Boundaries. - Usually, the Slapnice Member conformably overlies the older Mileč Member, generally with more or less sharp boundary. It is usually conformably overlain by the Skryje Member. The Slapnice Member may represent the whole thickness of the Buchava Formation at some outcrops, and in such a case it is covered directly by volcanites of the Křivoklát-Rokycany Complex.

Lithology. - This member is characterized by polymict clastic material in all constitutnt lithofacies. Graywackes are composed by sharply edged grains of quartz, feldspars and argillized or silicified fragments of shales and graywackes; more rarely clastic mica is also present (Fig. 12D, E). Locally, e.g. at the Slapnický mlýn, components of Precambrian cherts age are present. In all levels of the Slapnice Member, these graywackes represent the matrix of formerly described conglomerates (e.g. the Týřovice and Vosník conglomerates).

The composition of conglomerates is variable. At lower levels ("Týřovice Conglomerates" in former terminology)

Figure 12. Cross sections of lithotypes of the Buchava Formation. • A - Mileč Member, locality Skryje-Luh - lůmek (Fig. 1B/20). Well rounded grains composed of stable quartz (Q), rarely also cherts (C). B - Mileč Member, locality Skryje-Luh - lůmek (Fig. 1B/20). Lithofacies earlier designated as "Orthis Sandstones". Sharply edged grains of quartz (Q), feldspars (F) and argillized or silicified fragments of shales and greywackes (S). - C, C' - Slapnice Member, artificial outcrop at the road Luh-Skryje, about 60 metres west of the locality Skryje-Luh - lůmek (Fig. 1B/20), lithofacies earlier designated as "Týřovice conglomerates". Greywackes are composed by sharply edged grains of quartz (Q), cherts (C), feldspars (F) and argilized or silicified fragments of shales and greywackes (S). C'- crossed nicols. - D - Slapnice Member, artificial outcrop at the road Luh-Skryje, about 60 metres west of the locality Skryje-Luh - lůmek, lithofacies earlier designated as "Týřovice conglomerates". Pebbles are composed by grains of quartz $(\mathrm{Q})$, cherts $(\mathrm{C})$, and greywackes $(\mathrm{G})$. Basic matrix $(\mathrm{M})$ is composed by greywackes with sharply edged quartz. $\bullet$ E - Slapnice Member, natural outcrop in gorge near the locality Kouřimec (Fig. 1B/3). Lithofacies earlier designated as "Vosník conglomerates". Pebbles are composed by grains of quartz (Q), cherts $(\mathrm{C})$, greywackes $(\mathrm{G})$ and basaltic volcanic rocks (= spilites, $\mathrm{S})$. Basic matrix $(\mathrm{M})$ is composed by greywackes with sharply edged quartz. $\bullet \mathrm{F}-$ shales of the Skryje Member, natural outcrop at the stratotype locality Skryje-Luh (Fig. 1B/19). Clayey matrix with silty admixture of quartz, and cross-cutting of trilobite sclerite. $\cdot G$ - shales of the Skryje Member, natural outcrop below the Hotel Schindler in Skryje. Transition between siltstone (SILT) and shale (SH). Photo by T. Vorel. 

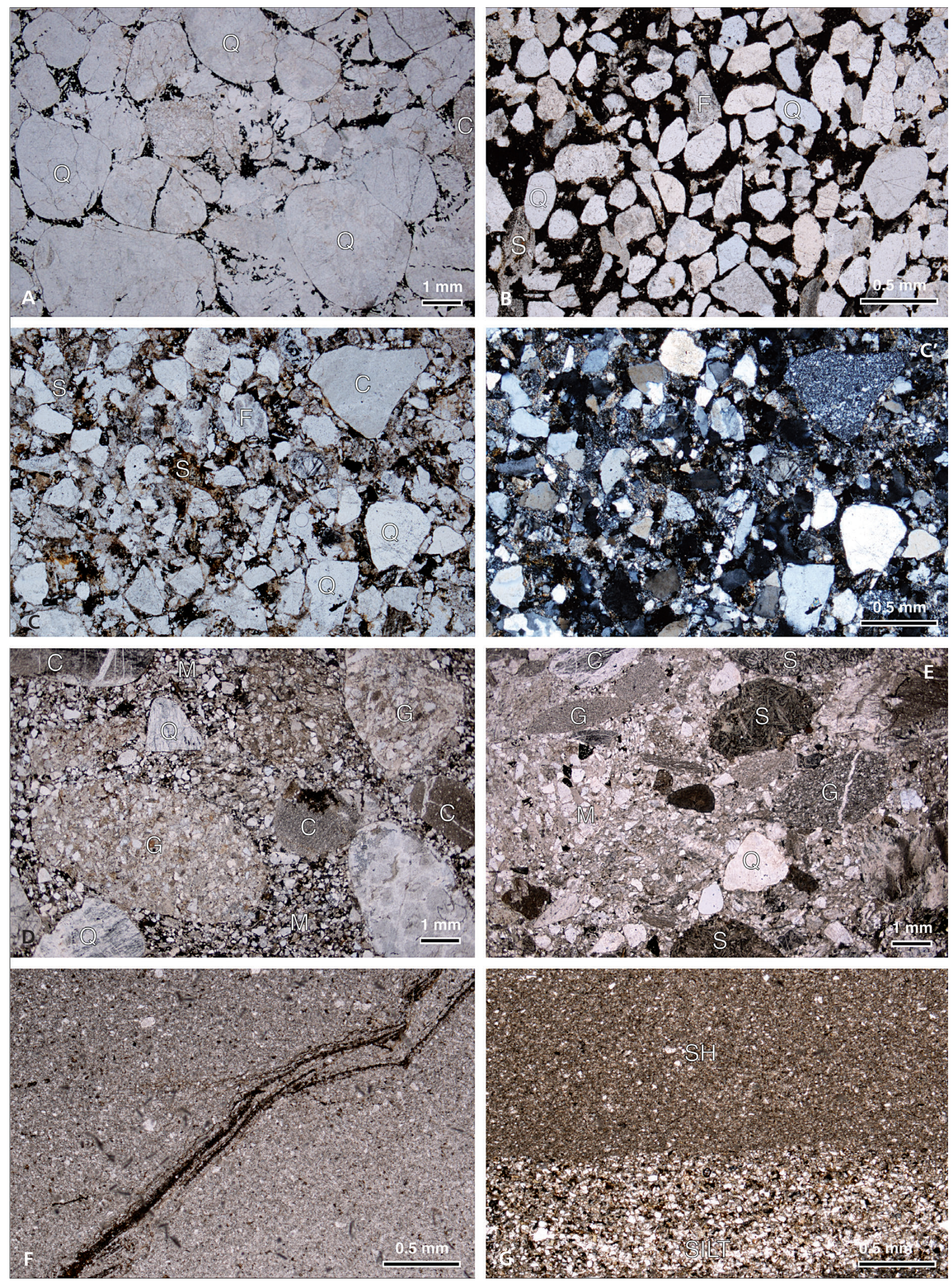
they are dominated by pebbles of graywackes, quartz and cherts associated with more or less rare spilites. In contrast, the stratigraphically higher levels contain comparatively larger amounts of basaltic vocanics (= spilites), and locally also granitoids. In contrast to the matrix, the pebbles are well rounded in all lithofacies.

Environment. - Deposits of a comparatively deeper environment, probably deeper shelf, was strongly influenced by the transport of well rounded terrestrial material in the NE part of the basin. These conglomerates represent deposition by gravity currents (debris-flows), due to transgressive-regressive pulses. The surprisingly high level of rounding of the pebbles has been explained by a long transport and/or redeposition before their deposition (see Petránek 1952a, b). During the sudden transport, i.e. by debris-flow, the pebbles were mixed with the graywacke matrix.

Discussion. - Jahn (1894, p. 148) used for the first time the term Tejřvicer Sandstein (= Tejřovice Sandstone) for the fossiliferous sediments at the locality "Pod trním" (Fig. 1B/17). However, later authors applied this designation sensu Kettner \& Kodym (1919, p. 6), who called this unit as polymict Tejřovice conglomerates and graywackes $c \beta$, including also finer sediments established in the lower third of the Cambrian sequence. All subsequent authors used this latter designation in such an extended conception. Another complication appeared with separation of the Vosník conglomerates c $\beta^{\prime}{ }_{3}$ as proposed by Kettner \& Kodym (1919, p. 6). These conglomerates were, in its original conception, established as a separate stratigraphical unit in the highest levels of the sequence. However, application by subsequent authors changed the conception of this unit into mere coarser grained local lithofacies, generally occurring in higher stratigraphical levels of the sequence in the eastern part of the sedimentary basin. Kukal (1971) was the first worker who showed that it was not possible to distinguish the Týřovice and the Vosník conglomerates on a petrographical basis; Kukal (1971, p. 82) thus discussed both units together. In reality, both the Týrovice and Vosník lithotypes, as originally established and characterized, could be substituted for each other through the whole sedimentary sequence, with the exception of basal levels in the north-eastern sector of the basin.

\section{Skryje Member (Krejčí 1877, emended and formalized)}

Derivation of name. - The member has been designated after the village of Skryje.
Stratotype. - Natural outcrops at the classical locality called Luh near Skryje, described in detail by Jahn (1896, pp. 731-733) and Chlupáč et al. (1998a); in this contribution Fig. 1B, locality 19 (= Skryje-Luh).

Boundaries. - The Skryje Member represents the finestgained lithotypes of the Buchava Formation in central part of the basin and thus it may be conformably underlain and overlain by coarser sediments of the Slapnice Member.

Lithology. - Shales are dominated by a dark, clayey matrix with slightly recrystallized clay minerals showing a tendency to mass extinction under crossed pollars. In shales, there is a silty to fine sandy admixture, being composed by fragments of quartz, feldspar and argillized pieces of rocks (Fig. 12E, F). Generally, common clastic mica flakes are accumulated in thin laminae within the shales and siltstones. The matrix of the shales contains clay minerals, namely chlorite and illite (see Kukal 1971).

Environment. - The sedimentary environment corresponds to the deeper part of the basin, most probably to deeper shelf. Clay with fine silt was deposited by turbiditic currents and thus the Skryje Member has at some outcrops a character of interbedded siltstone and shale beds with thin lamination.

The turbidites are commonly associated with larger slumps and debris-flows, which are responsible for deposition of coarser sediments, e.g. conglomerates, at diverse levels of the sequence (see also Kukal 1971).

\section{Buchava Formation (new)}

Derivation of name. The name relates to the outcrops near the gamekeeper's lodge Buchava; this area offers extensive exposures of Cambrian sediments (Fig. 1B/8).

Stratotype. - Natural outcrop on the right bank in the Zbirožský potok valley near the former Slap (= Slapský mlýn) is designated here as the stratotype section. A nearly complete section of the Buchava Formation is displayed above and below the road connecting Slapský mlýn and Skryje, east of the locality 8 (Fig. 1B/8).

Boundaries. - The lower boundary of the formation is well defined at the conspicuous angular unconformity associated with the Cadomian tectonic event. Any of the Mileč, Slapnice or Skryje members of the Buchava Formation can be the basal unit of the formation at different sectors of the basin. The Buchava Formation (Slapnice or Skryje Member) is capped by the late Cambrian to Lower Ordovician Křivoklát-Rokycany Complex. 


\section{Conclusions}

The here newly introduced lithostratigraphic subdivision for the Skryje-Týřrovice Basin comprises (Fig. 9):

(i) Mileč Member (monomict, usually quartzitic conglomerates and sandstones),

(ii) Slapnice Member (polymict conglomerates and sandstones, usually with graywacke cement), and

(iii) Skryje Member (graywackes to fine shales).

All these members representing different lithofacies within the Buchava Formation. The terms Tejřovice conglomerates, sandstones and graywackes and Vosník conglomerates and sandstones are recommended to be used as informal, descriptive, not formal, terms sensu their original description in the firstly published papers, only.

The Buchava Formation incorporates three members, namely the Mileč Member (including the basal breccia with superimposed monomict conglomerates to sandstones interfingering rarely with layers of graywackes); the Slapnice Member (prevailing sandstones to graywackes with lenses of usually fine-grained, rarely coarse-grained conglomerates and bodies of shales) and the Skryje Member (dominated by shales interfingering with graywackes and with restricted lenses to layers of sandstones).

\section{Acknowledgements}

This contribution benefited from the helpful improvement of the English and constructive suggestions made by A.W.A. Rushton (Natural History Museum, London) and O. Elicki (Bergakademie TU, Freiberg). The authors acknowledge long discussions with numerous specialists and collectors, as were the late V. Havlíček and M. Šnajdr (Czech Geological Survey), L. Marek (AV ČR), I. Chlupáč (Charles University, Prague), J. Kraft (West Bohemian University, Plzeň), V. Opatrný (Skryje) and V. Kordule (Př́bram). Numerous aspects were discussed and clarified also with P. Budil (Czech Geological Survey), P. Kraft and J. Marek (both Charles University, Prague), R. Prokop and V. Turek (both National Museum, Prague), R. Mikuláš and P. Šlehofer (AV ČR), M. Mergl (West Bohemian University, Plzeň), V. Kozák (Prague), L. Mandík (Příbram), R. Šarič (Czech Geological Survey), L. Henkl (Prague), M. Doubrava (Plzeň), M. Široký (Prague), and J. Herynk (Karlovy Vary). This study was supported by MSM 0021620855 and the Czech Science Foundation through the Project No. 205/06/1521.

\section{References}

Álvaro, J.J., Vizcaïno, D., Kordule, V., Fatka, O. \& Pillola, G.L. 2004. Some solenopleurine trilobites from the Languedocian (Late Mid Cambrian) of Western Europe. Geobios 37(2), 135-147. DOI 10.1016/j.geobios.2003.03.009 ANDRUSOv, D. 1925. Geologické poměry Zbirožska (La structure géologique de la région de Zbiroh dans la Bohême centrale). Sborník Státního geologického ústavu Československé republiky, Oddíl geologický 5, 53-101.

BARRANDE, J. 1846. Notice préliminaire sur le Systême silurien et les Trilobites de Bohême. 97 pp. Hirschfeld, Leipzig.

BARRANDE, J. 1852. Systême silurien du centre de la Bohême: Ière partie, Crustacès: Trilobites. 935 pp. Published by the author, Praha \& Paris.

BARRANDE, J. 1887. Systême silurien du centre de la Bohême. Volume VII. Classe des Echinodermes, Ordre des Cystidées. 233 pp. Praha \& Leipzig.

BouČEK, B. 1941. Geologické výlety do okoli pražského (Geological excursions in the surroundings of Praha). 202 pp. Melantrich, Praha.

BouČEK, B. 1951. Geologické vycházky do pražského okolí (Geological excursions in the surroundings of Praha). 242 pp. Př́rodovědecké vydavatelství, Praha.

CHLUPÁČ, I. 1999. Barrande's stratigraphic concepts, palaeontological localities and tradition - comparison with the present state. Journal of the Czech Geological Society 44(1-2), 3-30.

CHLUPÁČ, I. 2002. Explanatory remarks to reprinted Joachim Barrande Systême silurien du centre de la Bohême. Vol. I. Crustacès: Trilobites. 47 pp. Trilobit (Petr Materna), Praha.

Chlupáč, I., FAtKa, O., Prokop, R.J. \& Turek, V. 1998a. Výzkum klasické paleontologické lokality "Luh" ve skryjském kambriu (Research of the classical paleontological locality "Luh" in the Cambrian of Skryje). Journal of the Czech Geological Society 43(3), 169-173. [in Czech with English summary]

Chlupáč, I., HavlíčeK, V., KŘíž, J., Kukal, Z. \& ŠTorch, P. 1998b. Palaeozoic of the Barrandian. 183 pp. Český geologický ústav, Praha.

Drost, K., Linnemann, U., McNaughton, N., FatKa, O., Kraft, P., Gemlich, M., Tonk, C. \& MareK, J. 2004. New data on the Neoproterozoic-Cambrian geotectonic setting of the TepláBarrandian volcano-sedimentary successions: geochemistry, $\mathrm{U}-\mathrm{Pb}$ zircon ages, and provenance (Bohemian Massif, Czech Republic). International Journal of Earth Science (Geologische Rundschau) 93, 742-757.

DOI 10.1007/s00531-004-0416-5

Drost, K., Romer, R.L., Linnemann, U., FatKa, O., Kraft, P. \& MAREK, J. 2007. Nd-Sr-Pb isotopic record of Neoproterozoic Early Paleozoic siliciclastic rocks of the Barrandian (Bohemian Massif, Czech Republic), 191-208. In Linnemann, U., Nance, D.R., KRaft, P. \& Zulauf, G. (eds) The evolution of the Rheic Ocean: From Avalonian-Cadomian active margin to Alleghenian-Variscan collision. Boulder, Colorado. Geological Society of America Special Paper 423.

FATKA, O. 1990. Das Kambrium von Skryje und Týřovice, 12-17. In WeIDERT, K.H. (ed.) Klassische Fundstellen der Paläontologie, Band 2. Goldschneck.

FATKA, O. 2004. Association of fossils and history of research at the Týřovice - „Pod hruškou“ locality (Middle Cambrian, Skryje-Týřovice Basin, Barrandian area). Journal of the Czech Geological Society 49(3-4), 107-117. 
FatKa, O., Kraft, P. \& Szabad, M. 2011. Wiwaxia Walcott in Middle Cambrian of the Barrandian area (Czech Republic). Acta Palaeontologica Polonica 56, 427-431. DOI 10.4202/app.2009.0052

FatKa, O. \& Mergl, M. 2009. The 'microcontinent' Perunica: status and story 15 years after conception, 65-101. In BASSETT, M.G. (ed.) Early Palaeozoic peri-Gondwana terranes: New insights from tectonics and biogeography. Geological Society of London, Special Publications 325.

FatKa, O. \& Szabad, M. 2011. Burrowing trilobite caught in the act. Paläontologische Zeitschrift 85. DOI 10.1007/s12542-011-0102-4

FeISTMANTEL, C. 1885. O stupni primordiálním v Čechách (On the primordial level in Bohemia). Zprávy Spolku geologického v Praze 1(1), 3-6.

Geyer, G., Elicki, O., Fatka, O. \& Zylińska, A. 2008. Cambrian, 155-202. In McCANn, T. (ed.) Geology of Central Europe. Geological Society of London, London.

Hajná, J., Žák, J., Kachlík, V. \& Chadima, M. 2010. Subduction-driven shortening and differential exhumation in a Cadomian accretionary wedge: The Teplá-Barrandian unit, Bohemian Massif. Precambrian Research 176 (1), 27-45.

HAVLíčEK, V. 1966. Střední kambrium v širším okolí Skryjí (Middle Cambrian in the area of Skryje). Zprávy o geologických výzkumech $v$ roce $1965,103-105$.

HAVlíčEK, V. 1970. Pompeckium and Jamesella (Orthacea, Brachiopoda) in the Middle Cambrian of Bohemia. Věstník Ústředního ústavu geologického 45(5), 289-290.

HAVLIČEK, V. 1971. Stratigraphy of the Cambrian of Central Bohemia. Sborník geologických věd, Geologie 20, 7-52.

HavlíčEK, V. 1992. Kambrium, 31-55. In Chlupáč, I., Havlíček, V., KŘíž, J., KuKal, Z. \& ŠTorch, P. Paleozoikum Barrandienu (kambrium-devon). Czech Geological Survey, Praha.

HavlíčEK, V. 1994. Cambrian. In Klomínský, J. (ed.) Geological Atlas of the Czech Republic, Stratigraphy. Czech Geological Survey, Praha.

HavlíčEK, V. 1998. Cambrian, 20-38. In Chlupáč, I., HavlíčEK, V., KŘı̇ž, J., Kukal, Z. \& Šтorch, P. Palaeozoic of the Barrandian (Cambrian to Devonian). Czech Geological Survey, Praha.

Havlíčex, V., Horný, R., Chlupáč, I. \& Šnajdr, M. 1958. Průvodce ke geologickým exkurzím do Barrandienu (Führer zu den geologischen Exkursionen in das Barrandium). 170 pp. Ústřední ústav geologický, Praha. [in Czech and German]

HavlíčEK, V. \& ŠnAJdR, M. 1951. Cambrian and Ordovician in the Brdské Hřebeny and in the Jince area. Sborník geologických věd, Geologie 18, 145-276. [in Czech with English summary]

Hawle, I. \& Corda, A.J.C. 1847. Prodrom einer Monographie der böhmischen Trilobiten. Abhandlungen der königlichen böhmischen Gesellschaft der Wissenschaften 5(5), 119-292.

JAHN, J.J. 1893. Ueber das Tejřovicer Cambrium. Verhandlungen der kaiserlich-königlichen geologischen Reichsanstalt 1893(12), 267-273.
JAHN, J.J. 1894. Ueber bemerkenswerthe Fossilientypen aus dem böhmischen Cambrium. Verhandlungen der kaiserlich-königlichen geologischen Reichanstalt 1894(4), 148-149.

JAHN, J.J. 1896. Ueber die geologischen Verhältnisse des Cambrium von Tejřovic und Skrej in Böhmen. Jahrbuch der kaiserlich-königlichen geologischen Reichanstalt 45(4), 641-790.

JAHN, J.J. 1897. Kambrium mezi Lohovicemi a Tejřovicemi (The Cambrian between Lohovice and Tejřovice). Věstník Královské České společnosti nauk, Třída matematicko-př́rodovědecká, 1-24.

KATZER, F. 1888. Das ältere Palaeozoicum in Mittelböhmen. 42 pp. Verlag der J.G. Calve'schen k.k. Hof- und Universitäts-Buchhandlung, Ottomar Beyer, Prag.

Katzer, F. 1892. Geologie von Böhmen. 1606 pp. Verlag von I. Taussig, Prag.

KeTtNer, R. 1913. Dva profily ze Skrej (Two sections at Skreje). Sborník Klubu prrirodovědeckého v Praze za rok 1912(14), $1-7$.

KettNeR, R. 1914. Ein Beitrag zur Kenntnis des Kambrium von Skreje in Böhmen. Věstník Královské České společnosti nauk, Tř́ida matematicko-přirodovědecká 1913(2), 1-17.

KETTNER, R. 1916. O nové srovnávací petrografické sbírce „Barrandienu“ v Museu království českého (On new comparative petrological collection of the Barrandian area in the Museum of the Czech Kingdom). Časopis Musea Království českého, 82-94, 214-226.

KettNeR, R. 1919. Návrh na některé změny stratigrafického označování vrstev nejstarších oddílů Barrandienu (Proposal on some changes in stratigraphical designation of the oldest levels of the Barrandian area). Rozpravy České akademie věd a umění, Třída II (matematicko-přirodovědecká) 27(13), $1-14$.

KETTNER, R. 1922. Výzkum českého kambria v posledním desítiletí (Research of Bohemian Cambrian in the last ten years). Věda prírodní 3, 125-129.

KetTner, R. 1923. Kambrium skrejsko-tejřovické a jeho okolí (Cambrian of Skreje and Tejřovice and its surroundings). Sborník Státního geologického ústavu Československé republiky 3, 5-63.

Kettner, R. 1940. Kambrium, 12-17. In Andrusov, D., ČEPeK, L., Hynie, O., Kettner, R., Kodym, O. \& Urban, K. List Kralovice 4051. Geologický ústav pro Čechy a Moravu, Praha.

Kettner, R. \& Bouček, B. 1936. Cambrien. Tableaux synoptiques des formations du Barrandien. Travaux de l'Institut de Géologie et de Paléontologie de 1'Université Charles à Praha.

KettNer, R. \& Kodym, O. 1919. Nová stratigrafie Barrandienu (New stratigraphy of the Barrandian). Casopis Musea Království českého 93, 47-55.

KetTnER, R. \& SLAvík, F. 1928. Nový profil v algonkiu a kambriu tejřovickém (A new section through the Algonkian and Cambrian of Tejřrovice). Rozpravy České akademie věd a umění, Tř́da II (matematicko-př́rodovědecká) 38(10), 1-30. 
Kodym, O. 1948. Přednáška z geologie Českého masívu. Díl I. Úvod, přehled Českého masívu a barrandiensko-železnohorského pásma. VOPK, 1-208.

Kodym, O. 1953. Geologie českého masívu. Díl I. Úvod a zona barrandiensko-železnohorská. 232 pp. Státní pedagogické nakladatelství, Praha.

Kordule, V. 2006. Ptychopariid trilobites in the Middle Cambrian of Central Bohemia (taxonomy, biostratigraphy, synecology). Bulletin of Geosciences 81(4), 277-304. DOI 10.3140/bull.geosci.2006.04.277

KRAFT, P. \& MAREK, J. 1992. Nejstarší zpráva o „rokycanských kuličkách" a skryjsko-týřovickém kambriu. Časopis Národního muzea, Řada přirodovědovědecká 160(1-4), 51-55.

KREJČí, J. 1860. Geologie čili nauka o útvarech zemských se zvláštním ohledem na krajiny českoslovanské. Vols 1 -4 (incomplete). 510 pp. A. Augusta, Litomyšl.

KREJČí, J. 1877. Geologie čili nauka o útvarech zemských se zvláštním ohledem na krajiny českoslovanské. $2^{\text {nd }}$ edition. 1035 pp. Published by the author, Praha.

Krejčí, J. \& Feistmantel, K. 1885. Orographisch-geotektonische Übersicht des silurischen Gebietes im mittleren Böhmen. Archiv für naturwissenschaftliche Landesforschung von Böhmen 5(5), 1-124.

KrejČí, J. \& Feistmantel, K. 1890. Orografický a geotektonický přehled území silurského ve středních Čechách. Archiv pro prírodovědecký výzkum Čech 5(5), 1-94.

KuKaL, Z. 1970. Závěrečná zpráva o petrografickém výzkumu barrandienského kambria. (Final research report on Cambrian of the Barrandian area). Unpublished report, Geofond, Czech Geological Survey, Praha.

KukaL, Z. 1971. Sedimentology of Cambrian deposits of the Barrandian area. Sborník geologických věd, Geologie 20, 53-100.

KušTA, J. 1884. Ueber das Vorkommen von silurischen Thierresten in den Třemošnaer Conglomeraten bei Skrej. Věstník Královské České společnosti nauk 1884, 241-243.

KušTA, J. 1887. Nová geologická pozorování v Radnickém okolí. Věstník Královské České společnosti nauk 1887, 688-690.

KuŠTA, J. 1890. Živočišné zbytky v pásmu c $_{1}$ silurského stupně C. (Thierreste in der Zone $\mathrm{c}_{1}$ der Siluretage C). Věstník Královské České společnosti nauk 1890, 141-148.

KušTA, J. 1892. Příspěvky k seznání nejstarších zkamenělin českých a evropských vůbec. (Beiträge zur Kenntniss der ältesten böhmischen und überhaupt europäischen Versteinerungen). Věstník Královské České společnosti nauk 1892, 418-424.

Kušta, J. 1894. Poznámky o kambriu Tejřrovickém (Odpověd' panu Dru. J. Jahnovi). 15 pp. F. Šimáček, Praha.

Lefebvre, B. \& FAtKA, O. 2003. Palaeogeographical and palaeoecological aspects of the Cambrian-Ordovician radiation of echinoderms in Gondwanan Africa and peri-Gondwanan Europe. Palaeogeography, Palaeoclimatology, Palaeoecology 195, 73-97. DOI 10.1016/S0031-0182(03)00303-1

Linnemann, U., Pereira, F., Jefrries, T. E., Drost, K. \& Gerdes, A. 2008. The Cadomian Orogeny and the opening of the Rheic Ocean: The diacrony of geotectonic processes constrained by LA-ICP-MS U-Pb zircon dating (Ossa-Morena and Saxo-Thuringian Zones, Iberian and Bohemian Massifs). Tectonophysics 461, 21-43.

DOI 10.1016/j.tecto.2008.05.002

LiPOLD, M.V. \& KREJČí, J. 1860. Verhandlungen der kaiserlichköniglichen geologischen Reichsanstalt 11, 88-91.

Marr, J.E. 1880. On the Predevonian rocks of Bohemia. Quarterly Journal of the Geological Society 36, 591-619.

DOI 10.1144/GSL.JGS.1880.036.01-04.44

Maletz, J., Steiner, M. \& FatKa, O. 2005. Middle Cambrian pterobranchs and the Question: What is a graptolite. Lethaia 38(1), 73-85. DOI 10.1080/00241160510013204

Mašek, J., Straka, J., Hrazdíra, P., Pálenský, P., ŠtěPÁnek, P. \& Hưla, P. 1997. Geological and nature conservation map. Protected landscape area and biosphere reserve Křivoklátsko. Czech Geological Survey, Praha.

Mergl, M. \& Kordule, V. 2008. New Middle Cambrian lingulate brachiopods from the Skryje-Týřovice area (Central Bohemia, Czech Republic). Bulletin of Geosciences 83(1), 11-22. DOI 10.3140/bull.geosci.2008.01.011

Nance, R.D., Murphy, J.B. \& KepPIE, J.D. 2002. A Cordilleran model for the evolution of Avalonia. Tectonophysics 352, 11-32. DOI 10.1016/S0040-1951(02)00187-7

PAтоČKA, F. \& ŠTORCh, P. 2004. Evolution of geochemistry and depositional settings of Early Palaeozoic siliclastics of the Barrandian (Teplá-Baranndian Unit, Bohemian Massif, Czech Republic). International Journal of Earth Sciences 93, 728-741.

PetRÁNeK, J. 1952a. Skrytá diskordance ve skryjském kambriu. Rozpravy České akademie věd a umění, Třída II (matematicko-prírodovědecká) 62(4), 1-12.

PetráneK, J. 1952b. Zpráva o výzkumu týřovických a vosnických slepenců ve skryjském kambriu. Věstník Ústředního ústavu geologického 27, 219-221.

PoČTA, F. 1902. Geologická mapa Čech (Geological map of Bohemia). 30 pp. Fr. Řivnáč, Praha.

PoČTA, F. 1911. Stručný přehled geologie Čech. 136 pp. Bursík a Kohout, Praha.

PoMPECKJ, F. 1896. Die Fauna des Kambriums von Tejřovic und Skrej in Böhmen. Jahrbuch der kaiserlich-königlichen geologischen Reichanstalt 45, 495-615.

Prantl, F. 1942. Život českých pramoři. 390 pp. Přírodovědné vydavatelství, Praha.

PřIBYL, A. 1954. Seznam českých trilobitových rodů (Index of trilobite genera in Bohemia). Knihovna Ústředního ústavu geologického 25, 1-80.

RỦŽIČKA, R. 1939. Trilobiti nejstarší české kambrické fauny od Týřovic z Kamenné hůrky. Rozpravy České akademie věd a umění, Tř́da II (matematicko-přirodovědecká) 49(30), $1-12$.

RŮŽıčKA, R. 1944. O některých význačných trilobitech skryjského kambria (Über einige bezeichnende Trilobiten des Skreier Kambriums). Věstník Královské České společnosti nauk, Tř́da matematicko-př́rodovědecká, 1-26. 
SAlvador, A. (ed.) 1994. International Stratigraphic Guide A guide to stratigraphic classification, terminology and procedure. $2^{\text {nd }}$ edition. 214 pp. The Geological Society of America, Boulder, Colorado.

Smetana, V. 1918. O některých gastropodech z kambria skrejsko-tejřovického (On some gastropods from the Skreje-Tejřovice Cambrian). Rozpravy České akademie věd a umění, Třída II (matematicko-prrirodovědecká) 27(8), 1-13.

Smetana, V. 1921. O nejstarších paradoxidech skrejsko-tejřovického kambria (On the oldest paradoxids of the Cambrian of
Skryje-Týřovice). Sborník Státního geologického ústavu Československé republiky 1, 215-222.

ŠNAJDR, M. 1956. Poznámky ke stratigrafii kambria ve skryjské oblasti a v Železných horách (Remarks to the stratigraphy of the Cambrian in the area of Skryje and in the Železné hory). Věstník Ústředního ústavu geologického 31(2), 53-61.

ŠNAJDR, M. 1958. Trilobiti českého středního kambria. Rozpravy Ústředního ústavu geologického 20, 1-280.

VAughan, A.P.M. \& PANKhurst, R.J. 2008. Tectonic overview of the West Gondwana margin. Gondwana Research 13, 150-162. DOI 10.1016/j.gr.2007.07.004 